\title{
Interdisciplinary Analysis of the Lehi Horse: Implications for Early Historic Horse Cultures of the North American West
}

\author{
William Timothy Treal Taylor (D), Isaac Hart, Emily Lena Jones, Joan Brenner-Coltrain, \\ Jessica Thompson Jobe, Brooks B. Britt, H. Gregory McDonald, Yue Li, Chengrui Zhang, Petrus Le \\ Roux, Carlton Quinn Shield Chief Gover, Stéphanie Schiavinato, Ludovic Orlando, \\ and Patrick Roberts
}

\begin{abstract}
Although recognized as one of the most significant cultural transformations in North America, the reintroduction of the horse to the continent after $A D 1492$ has been rarely addressed by archaeological science. A key contributing factor behind this limited study is the apparent absence of equine skeletal remains from early historic archaeological contexts. Here, we present a multidisciplinary analysis of a horse skeleton recovered in Lehi, Utah, originally attributed to the Pleistocene. Reanalysis of stratigraphic context and radiocarbon dating indicates a historic age for this horse (cal AD 1681-1939), linking it with Ute or other Indigenous groups, whereas osteological features demonstrate its use for mounted horseback riding_perhaps with a nonframe saddle. DNA analysis indicates that the animal was a female domestic horse, which was likely cared for as part of a breeding herd despite outliving its usefulness in transport. Finally, sequentially sampled stable carbon, oxygen, and strontium isotope values from tooth enamel $\left(\delta^{13} \mathrm{C}, \delta^{18} \mathrm{O}\right.$, and $\left.{ }^{87} \mathrm{Sr}{ }^{86} \mathrm{Sr}\right)$ suggest that the horse was raised locally. These results show the utility of archaeological science as applied to horse remains in understanding Indigenous horse pastoralism, whereas consideration of the broader archaeological record suggests a pattern of misidentification of horse bones from early historic contexts.
\end{abstract}

Keywords: horseback riding, equestrianism, zooarchaeology, Utah, Lehi horse, horse pastoralism, Ute archaeology

Pese a ser reconocida como una de las más significativas transformaciones culturales en Norteamérica, la reintroducción del caballo en continente luego del año 1492 raramente ha sido abordada por la arqueología. Una razón de la escasez de tales trabajos es la aparente ausencia de restos esqueletarios de equinos en contextos arqueológicos históricos tempranos. Presentamos un análisis multidisciplinario de los restos de caballo recuperados en Lehi, Utah, los que fueron originalmente identificados como de la "Edad del Hielo" basados sobre el contexto geológico. El reanálisis del contexto estratigráfico junto con la

William Timothy Treal Taylor (william.taylor@ colorado.edu, corresponding author) — University of Colorado Museum of Natural History, Boulder, CO 80309, USA; Department of Archaeology, Max Planck Institute for the Science of Human History, 07745 Jena, Germany

Isaac Hart and Joan Brenner-Coltrain - Department of Anthropology, University of Utah, Salt Lake City, UT, USA

Emily Lena Jones $\mathbf{a}$ Department of Anthropology, University of New Mexico, Albuquerque, NM, USA

Jessica Thompson Jobe - Department of Geology and Geological Engineering, Colorado School of Mines, Golden, CO, USA

Brooks B. Britt $\square$ Department of Geological Sciences, Brigham Young University, Provo, UT, USA

H. Gregory McDonald $\square$ Bureau of Land Management Colorado State Office, Lakewood, CO, USA

Yue Li - School of Cultural Heritage, Northwest University, Xi’An, Shaanxi, China

Chengrui Zhang Department of Anthropology, Harvard University, Cambridge, MA, USA

Petrus Le Roux $\mathbf{a}$ Department of Geological Sciences, University of Cape Town, Rondebosch, 7700, South Africa

Carlton Quinn Shield Chief Gover - Department of Anthropology, University of Colorado Boulder, Boulder, CO 80309, USA/ Pawnee Nation of Oklahoma, Pawnee, OK 74058, USA

Stéphanie Schiavinato and Ludovic Orlando a Laboratoire d'Anthropobiologie Moléculaire et Imagerie de Synthèse, Faculté de Médecine Purpan, Bâtiment A, 37 allée Jules Guesde, Université Paul Sabatier, 31000 Toulouse, France

Patrick Roberts — Department of Archaeology, Max Planck Institute for the Science of Human History, 07745 Jena, Germany; School of Social Sciences, University of Queensland, St. Lucia, Queensland, Australia

American Antiquity 86(3), 2021, pp. 465-485

Copyright (C) The Author(s), 2021. Published by Cambridge University Press on behalf of the Society for American Archaeology. This is an Open Access article, distributed under the terms of the Creative Commons Attribution licence (http://creativecommons.org/licenses/by/4.0/), which permits unrestricted re-use, distribution, and reproduction in any medium, provided the original work is properly cited.

doi:10.1017/aaq.2020.109 
datación radiocarbónica indica una edad histórica para este caballo (1681-1939 años calibrados de la era), relacionándolo con grupos indígenas Ute u otros. A pesar de que parte del caballo fue destruido antes de su recuperación, la columna vertebral revela fisuras y osteofitos que indican que había sido montado y el uso de sillas sin marco, mientras que una artritis severa en la parte inferior de las extremidades habría reducido drásticamente su movilidad. El análisis de ADN demostró que el animal era una hembra doméstica, posiblemente cuidada como parte de una tropilla de cría. Finalmente, los valores de isótopos estables de carbono, oxígeno, y estroncio $\left(\delta^{13} \mathrm{C}, \delta^{18} \mathrm{O}, y^{87} \mathrm{Sr} /{ }^{86} \mathrm{Sr}\right)$ muestreados secuencialmente del esmalte dental sugieren que fue criada localmente en la región de Lehi. Estos resultados demuestran la utilidad de la aplicación del conocimiento arqueológico a los restos de caballo para entender el pastoralismo de esta especie por parte de las poblaciones indígenas. Por su parte, una consideración más amplia del registro arqueológico sugiere un patrón de identificación errónea de huesos de caballo en contextos históricos tempranos.

Palabras clave: montar a caballo, equitación, zooarqueología, caballo de Lehi, pastoralismo de caballos, arqueología de los Ute

$\mathrm{T}$ The history of the American West is deeply intertwined with the domestic horse. The genus Equus first evolved in the Pliocene (Blancan) steppes of the Americas, radiating outward into Eurasia and Africa sometime during the last approximately three million years (Orlando et al. 2013). The ecological landscape of North America evolved with these wild equids, and the first people to move into the continent had a relationship with horses - both as prey species (Bourgeon et al. 2017; Kooyman 2006) and as a source of raw material for bone tools (Webb and Hemmings 2006) - along with other megafauna up to the end of the Pleistocene. Current radiocarbon dates of fossil equids in North American place their disappearance about approximately 10,000 years ago (Haile et al. 2009), and the Americas were without horses until the Spanish introduced the domestic horse (Equus caballus) and donkey (Equus asinus) after $\mathrm{AD} 1492$.

Horses were first reintroduced to the Americas by Spanish colonists in the sixteenth century, and they were swiftly integrated into the culture, economy, and lifeways of many Indigenous peoples, especially in the North American West (Mitchell 2015). Some Indigenous groups established territorially dominant politics and became "horse nations" rivaling European powers on the continent (Hämäläinen 2008; Mitchell 2015). Although historic records shed some light on the development of riding and breeding horses among Indigenous North Americans, these processes took place largely outside the attention of European observerslimiting the explanatory power of history to address when, why, and how horses were first integrated into Indigenous societies in the Americas (Jones and Gabe 2015).
The limitations of the Euro-American historical record in sixteenth- and seventeenth-century North America parallel challenges in understanding early human-horse relations in prehistoric Eurasia, where zooarchaeology has proven to be a valuable source of data about the early stages of horse domestication, management, and use. Osteological study of horse remains in natural history collections and comparison with the archaeological record have revealed characteristic damage patterns to the equine skeleton caused by metal bit use (Anthony et al. 1991; Bendrey 2007), riding with or without a frame saddle (Bartosiewicz and Gal 2013; Levine et al. 2005), heavy exertion (Taylor et al. 2015), and bridle nosebands (Taylor and Tuvshinjargal 2018). Biomolecular study of equid remains can provide sex and species identifications of bone fragments with a high success rate, even in the absence of sufficient DNA for more extensive sequencing (Schubert et al. 2017), whereas stable isotope analysis can shed light on seasonal movements, trade, and supplementary feeding practices (Bendrey et al. 2009; Makarewicz et al. 2018). Such a combination of zooarchaeological and biomolecular analyses of horse remains promises to reveal detailed insights into how horses were managed, ridden, and integrated into ancient lifeways-even in the absence of historical records.

One of the obstacles to the application of a multiproxy zooarchaeological approach to the early historic era in the North American West is the limited sample of horse remains identified in relevant museum collections. For example, in the entire state of Wyoming just two early historic horse specimens plausibly associated with Indigenous cultures have been identified by 
Thornhill (2016). It is possible, however, that North America's rich paleontological record of Pleistocene horses, combined with the wellknown significance of horses in historic EuroAmerican societies, has resulted in the regular misclassification of Indigenous archaeological horses as either Euro-American or Ice Age in origin. Indeed, one of the two early historic horses identified by Thornhill from the site of Black's Fork, Wyoming, was originally suspected to be the remains of a modern or ancient wild horse that died in that location from a natural deathuntil it became clear that the horse had been buried as part of a ritual feature, along with three coyote skulls (Eckles et al. 1994). Similarly, Scott and colleagues (2010) identified an early historic horse skull that had remained misidentified for a century, even earning its own Pleistocene taxon-Equus laurentius - before radiocarbon dating and a thorough morphological comparison revealed it to be historic. Furthermore, undated "intrusive" horse burials are sometimes reported from Indigenous archaeological sites after being ascribed to nonnative ranchers or settlers (Supplemental Figure 1), despite clear archaeological evidence documenting that horses were sometimes integrated into
Indigenous funerary and ritual inhumation (e.g., O'Shea and Ludwickson 1992). These examples suggest that, when confronted with ancient horse assemblages, researchers may often misidentify archaeological horse remains associated with Indigenous cultures.

\section{The Lehi Horse}

In the spring of 2018, residents of Lehi, Utah-a city located at the foot of the northern Wasatch Front in the Provo metropolitan area at an elevation of approximately $1,390 \mathrm{~m}$ asl (Figure 1) discovered equine skeletal remains during new construction. The discovery was reported to researchers at the nearby Museum of Ancient Life, who visited the site and determined that the horse was located in sandy lacustrine deposits of Pleistocene Age. Researchers noted several skeletal pathologies, including arthritis, and determined that the animal was small, about "the size of a Shetland pony" (Holson 2018). Although no formal analysis was conducted, the animal was determined to be an elderly Pleistocene horse-perhaps Haringtonhippus francisci (Heintzman et al. 2017)—which had died a

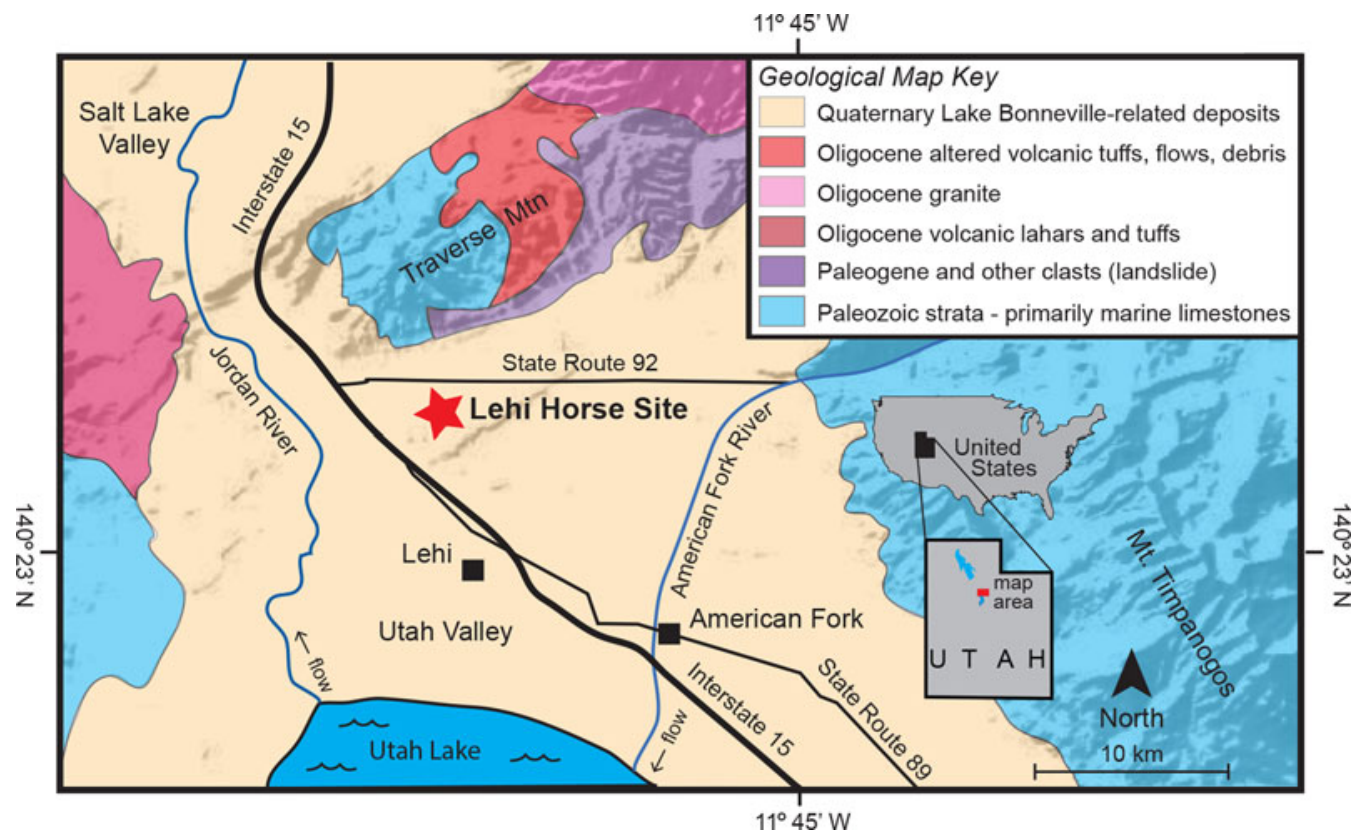

Figure 1. Lehi horse site within Utah Valley and locations mentioned in the text, along with topography and a simplified geologic map derived from Hintze and colleagues (2000). 
natural death on the Provo shoreline of what was then Lake Bonneville (Holson 2018) and thought to date to approximately $16,000 \mathrm{yr}$ BP (Benson et al. 2011; Oviatt 2015).

Although the evidence for an Ice Age origin was intriguing, given that Pleistocene horse remains have been previously reported from shoreline deposits along the Wasatch Front associated with Lake Bonneville (Milligan and McDonald 2017; Nelson and Madsen 1987), we identified several key aspects of the Lehi horse (reposited at the BYU Museum of Paleontology, specimen \#BYU 43000, locality \#2428) that raised questions about its age, paleontological associations, and context. The available excavation documentation (Figure 2) suggests a pit-like feature in the likely Pleistocene sands, partially infilled with a dark organic layer and horizontally bedded sands and silts (Supplemental Text 1). The presence of rip-up clasts overlying the horse remains supports at least some fluvial incision and deposition during or following burial. The feature's irregular morphology led the original investigators to conclude that this pit was not produced by industrial machinery and was thus Pleistocene in origin (i.e., that the horse remains rest at the base of a small channel fill rather than in an anthropogenic pit). During excavations, however, investigators also recovered a human-modified chert flake (specimen BYU 43001) from the "overburden" (Figure 3) either the fluvial sand and gravel deposits or organic overburden units shown in Figure 2. A large amount of cortex and large flake scars

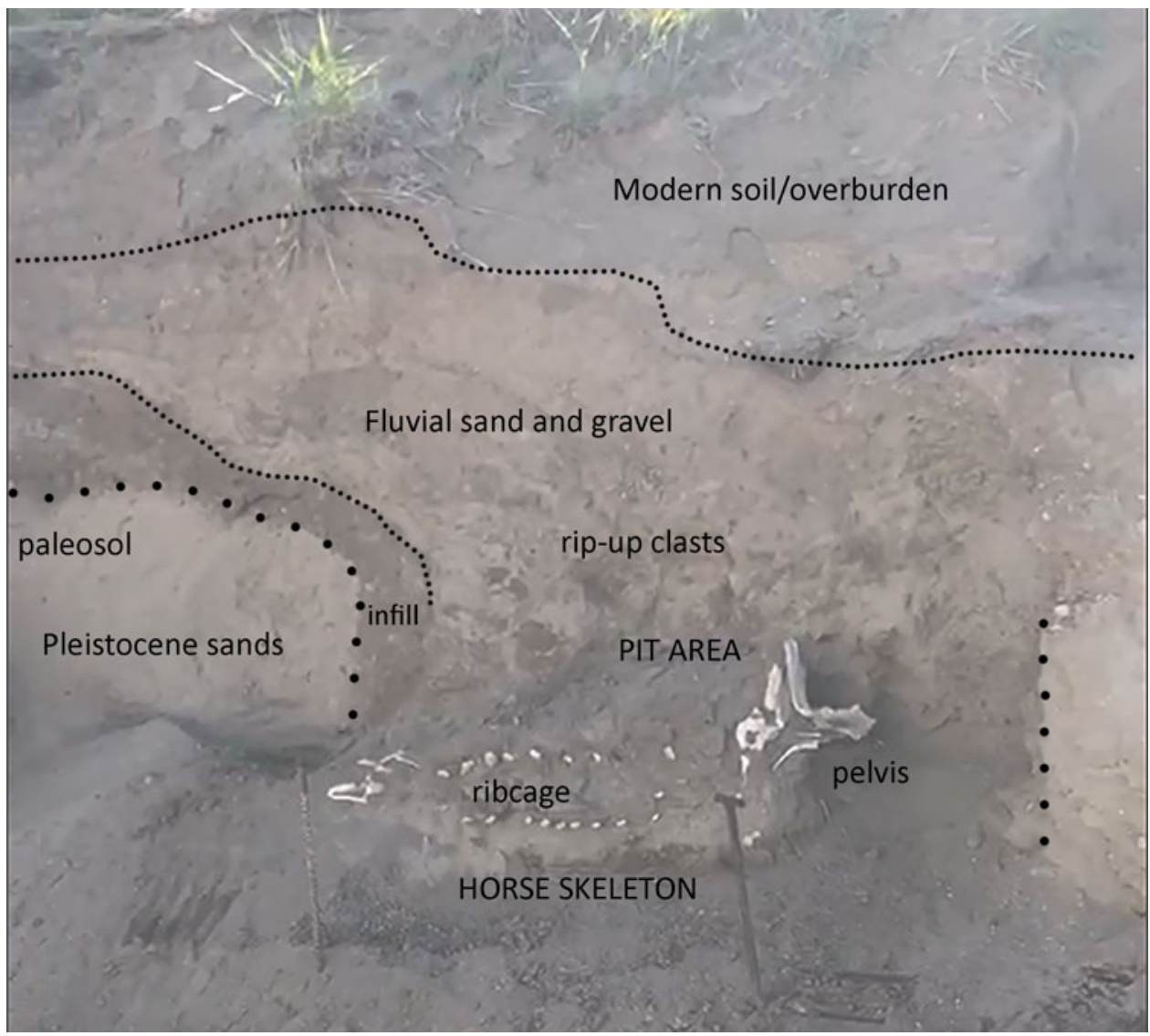

Figure 2. Stratigraphic profile of the Lehi horse excavation, showing a probable pit incised into Pleistocene sands and filled with dark organic soil below horizontally bedded sands and muds, and overlain by recent fluvial deposits. (Color online) 


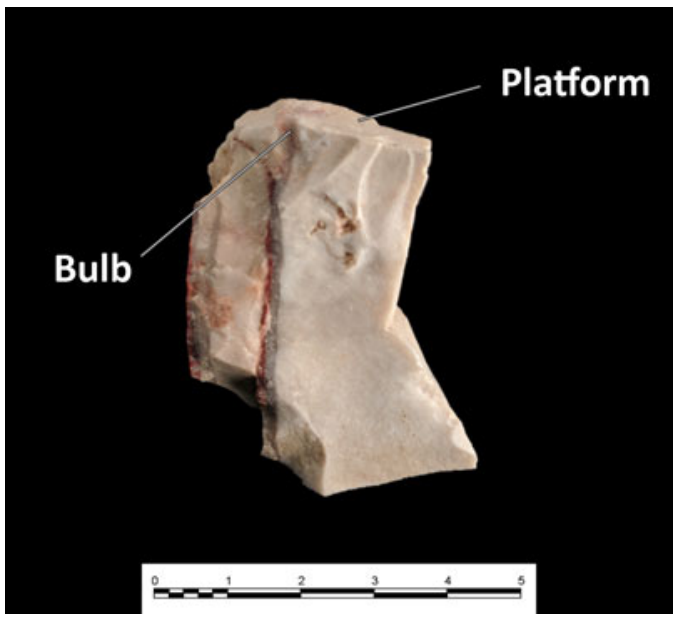

Figure 3. Modified broken chert flake recovered from the "overburden" during initial excavations of the Lehi horse (unprovenienced). (Color online)

indicate that this flake was probably produced during early-stage reduction. The precise provenience of this object was not recorded. To us, however, this indicated an Indigenous presence at the location of the Lehi horse after burial. Moreover, our preliminary examination of the horse's vertebral column revealed osteophytes, cracking, and impinging spinous processes-
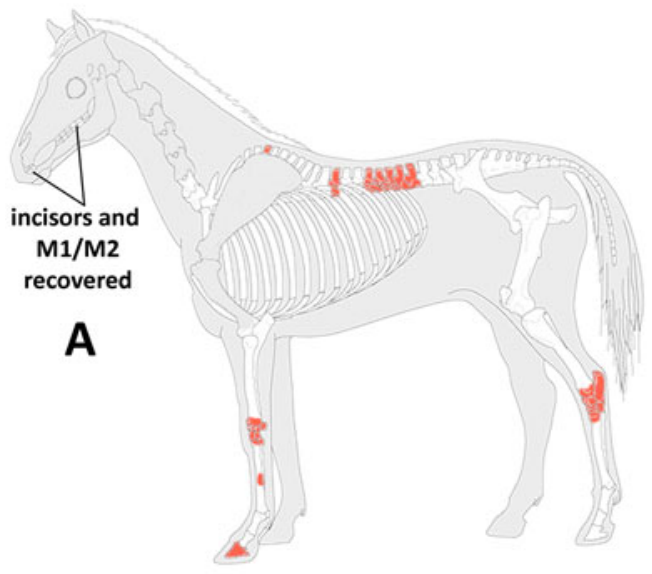

pathological features that are not commonly observed in wild equids and that are typically associated with mounted horseback riding (Figure 4; Levine 1999; Li et al. 2020). These findings raised the possibility that the Lehi horse was historic or protohistoric rather than Pleistocene in age.

If the Lehi horse was indeed a misidentified, early historic horse managed by Indigenous peoples, it represents a unique opportunity to explore how horses were used, managed, and cared for in Native societies beyond the limited documentation in Euro-American historical records. Here, we apply osteological and biomolecular analyses to evaluate the age and domestic status of the Lehi horse, and we explore the implications of our findings for the sixteenth-century reintroduction of horses to the Americas.

\section{Materials and Methods}

\section{Radiocarbon Dating}

To assess the age of the Lehi horse, we selected an intact upper molar (the upper right M1, or 109 in the modified Triadan system) for radiocarbon dating at the Oxford Radiocarbon Accelerator Unit (ORAU) in Oxford, UK. The ORAU

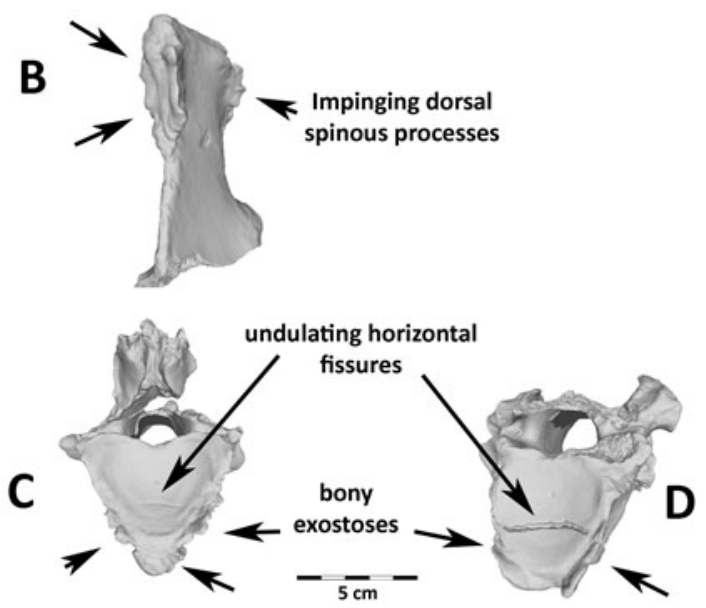

Figure 4. Recovered bones and osteo pathologies: (a) stylized horse skeleton showing missing bones (gray), recovered bones (white), and recovered pathological bones (red); many teeth were recovered, but much of the head/neck was destroyed before excavation. Examples of diagnostic vertebral pathologies (b-d) linked with mounted horseback riding. These include (b) impinging dorsal spinous processes on thoracic vertebra 13, (c, d) undulating, irregular horizontal fissures in the articular surface on the caudal end of the centra, and a proliferation of bony exostoses on thoracic vertebrae (c) 16 and (d) 17. 
performed routine pretreatment and measurement procedures (Brock et al. 2010), extracting dentine and combusting it in an elemental analyzer before graphitizing and measuring results on an HVEE accelerator, alongside blanks and standards, which were used to perform contamination calculations and data corrections. We calibrated our resulting radiocarbon measurement in OxCal using the IntCal13 calibration dataset (Reimer et al. 2013) to produce a calendrical estimate for the horse's age.

\section{Osteological Study}

We assessed the age of the Lehi horse using dentition (Evans et al. 2006) and evaluated the skeleton for evidence of pathologies (Bartosiewicz and Gal 2013). We focused particularly on identifying health conditions or osteological changes indicative of-or related to-human activity, including vertebral pathologies associated with mounted horseback riding (Levine et al. 2005) and anthropogenic modifications to the dentition associated with human veterinary care (Taylor et al. 2018). Because the cranium of the horse had been shattered, we were unable to assess premolar changes caused by metal bit use (Bendrey 2007), nasal or premaxillary remodeling associated with bridle use (Taylor and Tuvshinjargal 2018) and heavy exertion (Taylor et al. 2015), or bone formation at the nuchal crest often associated with horseback riding or confinement (Bendrey 2008; Taylor et al. 2015).

\section{Isotope Analysis}

Analyses of the stable isotope composition of ancient horse remains have the potential to provide important environmental context and reveal aspects of forage, pastoral care, and movement. To shed light on the life history of the Lehi horse, we analyzed the carbon, oxygen, and strontium isotope chemistry of Lehi horse dentition, comparing these data to modern climate and environmental reference data from the region to assess how the horse moved during its lifetime and identify sources of dietary food and water.

$\delta^{13} C$ Background. In the terrestrial ecosystems of the Intermountain West, the primary source of variation in stable carbon isotopes $\left(\delta^{13} \mathrm{C}\right)$ is the photosynthetic pathway $\left(\mathrm{C}_{3}, \mathrm{C}_{4}\right.$, CAM) employed by native plant taxa. The distribution of $\mathrm{C}_{3}$ versus $\mathrm{C}_{4}$ taxa in the region is the result of complex interactions between a combination of environmental factors, including temperature, precipitation regime, soil moisture, snow cover, vegetation, and evapotranspiration-all of which vary significantly through space and across time (Notaro et al. 2010). In general, $C_{4}$ grasses and forbs are more abundant in the American Southwest, with high summer temperatures and a precipitation regime dominated by the North American Monsoon (NAM), whereas $\mathrm{C}_{3}$ taxa dominate the Great Basin, with its cooler environments, significant winter precipitation, and associated spring snowmelt events (Cotton et al. 2016; Wertin et al. 2015). Elevation has a less significant impact on $\mathrm{C}_{3} / \mathrm{C}_{4}$ abundance in this region than do temperature and seasonality of precipitation (Paruelo and Lauenroth 1996). Within the $\mathrm{C}_{3}$ pathway, plants respond to reductions in water availability by stomatal closure, leading to a slight increase in leaf $\delta^{13} \mathrm{C}$ values (Farquhar et al. 1989). Environmentally driven shifts in intra-taxonomic plant $\delta^{13} \mathrm{C}$ caused by moisture stress are typically relatively minor-around 2\%o or less (Ehleringer 1989).

Current native grasses in the Lehi region consist primarily of $\mathrm{C}_{3}$ taxa. Cotton and colleagues (2016) characterize the Lehi region as between $0 \%$ and $10 \% \mathrm{C}_{4}$ vegetation. Northern Utah is devoid of $\mathrm{C}_{4}$ grasses, but $\mathrm{C}_{4}$ forbs such as Atriplex - also consumed by horses-are present and begin greening in mid-spring, providing a seasonal source of higher $\delta^{13} \mathrm{C}$ values during this time. Although plants expressing the CAM photosynthetic pathway (Lee 2010) can have values overlapping those of $\mathrm{C}_{4}$ plants, causing interpretive challenges in some settings (e.g., Smith et al. 2014), CAM plants in the study area consist largely of desert succulents unlikely to be consumed by grazers such as horses. Variation in forage $\delta^{13} \mathrm{C}$ is passed up the food web, with isotopic enrichment between diet and tooth enamel carbonates averaging $+14.1 \%$ o $( \pm 0.5)$ in a wide range of ungulate mammals (Cerling and Harris 1999:352) and $+13.8 \%$ o $( \pm 1.9)$ in horses specifically (Cerling and Harris 1999:349; see also Passey et al. 2005). Prior to fossil fuel depletion of atmospheric $\mathrm{CO}_{2}$, 
fractionation during photosynthesis led to $\mathrm{C}_{3}$ and $\mathrm{C}_{4}$ grasses expressing an average $\delta^{13} \mathrm{C}$ value of approximately $-25 \%$ and $-10 \%$ respectivelyabout $2 \%$ enriched over modern plant taxa (Dombrosky 2020).

$\delta^{18}$ O Background. Accurate interpretation of archaeological $\delta^{18} \mathrm{O}$ relies on contextualization with modern and ancient climate data (e.g., Hamilton et al. 2018). $\delta^{18} \mathrm{O}$ of environmental water is influenced by a suite of factors, including temperature, altitude, rainfall amount, aridity, seasonal precipitation patterns, and distance from the coast (Cerling et al. 2010). For example, as water-vapor masses move upslope, $\mathrm{H}_{2}^{18} \mathrm{O}$ preferentially rains out, accelerated by declines in temperature. $\mathrm{H}_{2}^{18} \mathrm{O}$ also rains out as water-vapor masses move inland, progressively depleting $\delta^{18} \mathrm{O}$ values relative to coastal moisture, although this effect is less marked in cold (versus warm) precipitation events. Thus, the $\delta^{18} \mathrm{O}$ value of water is influenced by temperature both within and across altitudinal and latitudinal gradients (Daux et al. 2005; Fricke and O'Neil 1999). Generally, colder winter temperatures and precipitation lead to lower water $\delta^{18} \mathrm{O}$ values, whereas summer aridity and increased temperatures enrich water $\delta^{18} \mathrm{O}$ (Dansgaard 1964). In the Lehi region, most precipitation is concentrated in winter and early spring (Figure 5). Here, deep snowpack with lower $\delta^{18} \mathrm{O}$ values accumulates at elevations in the Wasatch range, reaching $3,650 \mathrm{~m}$ asl $(\sim 12,000$ feet). Accordingly, as snowpack melts during late spring and early summer, modern $\delta^{18} \mathrm{O}$ data from the Jordan River near Lehi (Coplen and Kendall 2000) exhibit consistently lower $\delta^{18} \mathrm{O}$ values due to discharge of snowmelt into numerous alpine streams flowing downslope into Utah Lake and the Jordan River drainage.
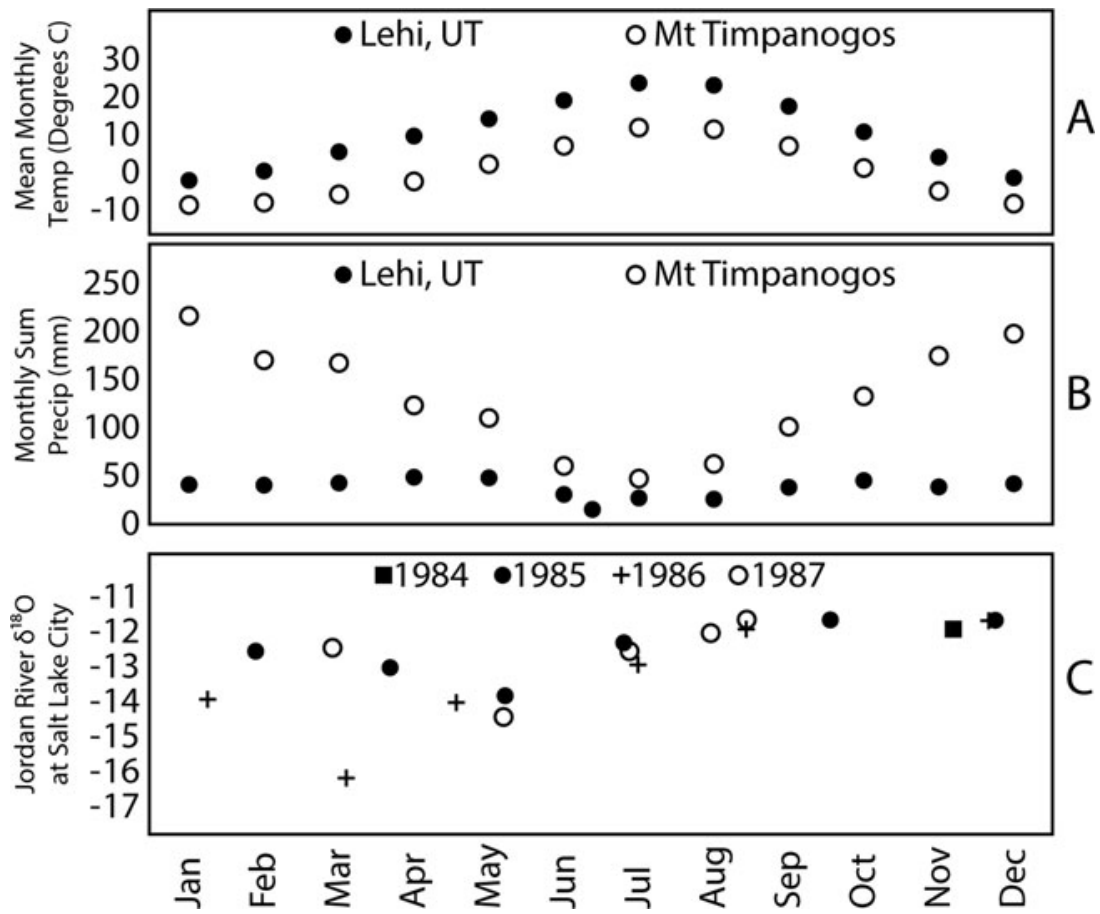

Figure 5. (a) monthly temperature at Lehi, Utah (1,391 $\mathrm{m}$ asl), and at the nearby peak of Mount Timpanogos, roughly $15 \mathrm{~km}$ east of the Lehi site (3,582 m asl), showing warmest temperatures in the summer, June-August; (b) monthly total precipitation at Lehi and Mt. Timpanogos, showing very low precipitation year-round at Lehi itself and higher precipitation with a pronounced decrease in the summer months (June-August) at higher elevations; (c) stable oxygen isotope values for the Jordan River between 1984 and 1987 (Coplen and Kendall 2000), showing $\delta^{18} O$ depletion during spring snowmelt. 
Although other processes, such as leaf evapotranspiration, may have minor impacts on the $\delta^{18} \mathrm{O}$ value of forage (Pederzani and Britton 2019), horses are obligate drinkers, deriving most of their moisture intake from imbibed water. During summer months, whether drinking from standing or flowing sources, imbibed water will likely express evaporatively enriched $\delta^{18} \mathrm{O}$ values relative to snowmelt - the primary source of spring and early-summer drinking water. Thus, in temperate regions, the $\delta^{18} \mathrm{O}$ values of obligate drinkers-such as horses-primarily reflect seasonally driven variation in $\delta^{18} \mathrm{O}$ values of water bodies (Levin et al. 2006; Pederzani and Britton 2019; Roberts et al. 2018). Significantly, the process of enamel mineralization and maturation allows chronologically ordered isotopic changes to be studied (Balasse 2002; Sponheimer et al. 2006), documenting seasonal patterns of movement or environmental conditions (Balasse 2002; Makarewicz et al. 2018). Although water cisterns may also bias archaeological $\delta^{18} \mathrm{O}$ values, there is no evidence of the use of such systems for horse management by Indigenous peoples (Ewers 1955). As a result, $\delta^{18} \mathrm{O}$ values from the Lehi horse should assess the input of local water sources and/or associated movements during the animal's life.

${ }^{87} \mathrm{Sr} /{ }^{86} \mathrm{Sr}$ Background. Strontium isotope ratios $\left({ }^{87} \mathrm{Sr} /{ }^{86} \mathrm{Sr}\right)$ of tooth enamel have been used to track mobility based on the principle that bedrock of different ages and compositions have distinctive strontium isotope values that do not fractionate from the bedrock to the biosphere (Graustein and Armstrong 1983; Montgomery 2010). Older lithic formations have relatively higher ${ }^{87} \mathrm{Sr} /{ }^{86} \mathrm{Sr}$ in comparison to younger bedrock, while distinctive mineral content leads to characteristic ${ }^{87} \mathrm{Sr} /{ }^{86} \mathrm{Sr}$ based on rock "type" (Capo et al. 1998). The surface of Utah Valley is draped by Late Pleistocene Lake Bonneville-related sediments, and the bases of the surrounding mountains are covered with the lake's shoreline deposits, wave-cut terraces, and related deltaic deposits and alluvial fans. The city of Lehi lies at the north end of Utah Valley, and the burial is incised into a Lake Bonneville shoreline deposit. The mountains encompassing Utah Valley are composed primarily of Paleozoic marine carbonates, which on the north end of the valley were injected by intrusive (granite) - and overlain by extrusive (tuff) - igneous rock units. Tens of kilometers to the northeast and at higher elevations, the headwaters of the Provo River, which drains into Utah Lake, flow along Late Precambrian strata that have been metamorphosed to varying degrees (Biek 2005). These mixed source terrains result in a landscape expected to vary in bedrock strontium-isotope content (Figure 1).

Differential weathering of rocks with varied ${ }^{87} \mathrm{Sr} /{ }^{86} \mathrm{Sr}$ ratios, as well as the geographic variability of hydrology and aeolian transport, suggests that the ${ }^{87} \mathrm{Sr} /{ }^{86} \mathrm{Sr}$ of soils and plants-and individuals consuming them-may not be identical to bedrock ratios (Montgomery 2010). In the absence of detailed baseline data, the sampling of different points along the vertical axis of a tooth can still provide insight into whether an individual moved during enamel formation. This is because the strontium isotope ratio of animal forage, taken up primarily from soils, is incorporated into tooth enamel during the process of mineralization.

Horse Tooth Mineralization and Development. The first molar of the horse begins to mineralize at around two weeks of age, and it continues to mineralize over the first 24 months of life (Hoppe et al. 2004). Between the ages of 8 and 12 months, this tooth erupts through the gums and begins to wear (Evans et al. 2006; Hoppe et al. 2004), and the tooth continues to mineralize away from the crown vertically at a rate of roughly $3.5-4.0 \mathrm{~cm} /$ year (Hoppe et al. 2004). The tooth reaches a total "crown height" (the distance between the lowest portion of the root juncture and the occlusal surface) of 80$90 \mathrm{~mm}$ or more (Levine 1982). Because our sample is derived from the lower portion of this tooth, we infer that our signal derives from the horse's second year of life. The oblique orientation of enamel formation suggests that each sample taken perpendicular to the vertical axis of a tooth averages a short but thus far undocumented period of mineralization of up to several months (Hoppe et al. 2004).

Horses typically complete the process of weaning by the age of roughly 8-9 months, although this process can be as short as 4 months in domestic animals and may last as long as a 
year (Waran et al. 2008). Given that mammalian milk is elevated in $\delta^{18} \mathrm{O}$ and lower in $\delta^{13} \mathrm{C}$ relative to imbibed water and herbivore forage, respectively, the interpretation of equid stable isotope data can be confounded by enamel values laid down prior to weaning (Zazzo et al. 2002). This bias is particularly problematic with equid M1 data because the tooth mineralizes during the first two years of the animal's life. The advanced age of the Lehi horse, however, means that the upper $40+\mathrm{mm}$ or so of tooth has been worn away through occlusal wear. We sampled the remaining $18 \mathrm{~mm}$ of enamel on a very worn M1 crown; this vertical section almost certainly mineralized in the second phase of tooth growth after weaning (Hoppe et al. 2004). As a result, although suckling clearly impacts both enamel $\delta^{13} \mathrm{C}$ and $\delta^{18} \mathrm{O}$, and may bias strontium ratios, these processes are unlikely to have impacted our data.

Protocols. The lower right first molar (M1/ 409 in the modified Triadan system) was sequentially sampled for enamel stable carbon and oxygen isotope values $\left(\delta^{13} \mathrm{C}\right.$ and $\left.\delta^{18} \mathrm{O}\right)$ at the Stable Isotope Laboratory Facility in the Department of Archaeology, Max Planck Institute for the Science of Human History in Jena, Germany. Sampling was conducted at the base of the tooth root on the lingual margin, moving up at $2 \mathrm{~mm}$ intervals to a distance of $18 \mathrm{~mm}$ above the root, immediately below the occlusal surface of this heavily worn M1.

Enamel powder was pretreated by a wash in $1.5 \%$ sodium hypochlorite for 60 minutes, followed by three rinses in purified $\mathrm{H}_{2} \mathrm{O}$, before $0.1 \mathrm{M}$ acetic acid was added for 10 minutes, followed by another three purified $\mathrm{H}_{2} \mathrm{O}$ rinses (per Lee-Thorp et al. 2012; Roberts et al. 2017; Sponheimer et al. 2005). The resulting residues were freeze-dried overnight before reaction with $100 \%$ phosphoric acid. Gases evolved from the samples were analyzed for their stable carbon and oxygen isotopic composition using a Thermo GasBench II connected to a Thermo Delta V Advantage Mass Spectrometer at MPI-SHH. $\delta^{13} \mathrm{C}$ and $\delta^{18} \mathrm{O}$ values were compared against International Standards (IAEA-603 $\left[\delta^{13} \mathrm{C}=2.5 ; \delta^{18} \mathrm{O}=-2.4\right]$; IAEA-CO-8 $\left[\delta^{13} \mathrm{C}=\right.$ $\left.-5.8 ; \delta^{18} \mathrm{O}=-22.7\right]$; USGS44 $\left[\delta^{13} \mathrm{C}=-42.2\right]$ ) and in-house standard (MERCK $\left[\delta^{13} \mathrm{C}=-41.3\right.$; $\left.\left.\delta^{18} \mathrm{O}=-14.4\right]\right)$. Replicate analysis of MERCK standards indicates that machine measurement error is $c . \pm 0.1 \%$ or for $\delta^{13} \mathrm{C}$ and $\pm 0.2 \%$ or $\delta^{18} \mathrm{O}$. Overall measurement precision was assessed by measurement of repeat extracts from a bovid tooth enamel standard $(n=20, \pm$ $0.2 \%$ for $\delta^{13} \mathrm{C}$ and $\pm 0.2 \%$ for $\delta^{18} \mathrm{O}$ ).

We also sampled the same tooth in three locations for strontium isotope analysis- the base of the tooth root $(0 \mathrm{~mm})$, the middle of the sampled section $(10 \mathrm{~mm})$, and the crown $(18 \mathrm{~mm})$. Chemical sample preparation for strontium isotope analysis was performed in the clean chemistry laboratory of the MC-ICP-MS facility, Department of Geological Sciences, University of Cape Town. Strontium isotope ratio analysis was performed using the $\mathrm{Nu}$ Instruments $\mathrm{Nu}$ Plasma HR MC-ICP-MS in this facility (after Copeland et al. 2008). Twenty milligrams of the sampled tooth enamel powder were dissolved in $2 \mathrm{~mL}$ concentrated $\mathrm{HNO}_{3}$ in a closed Teflon beaker. The beaker was placed on a hotplate at $140^{\circ} \mathrm{C}$ for an hour, after which the sample was dried down and redissolved in $1.5 \mathrm{~mL} 2 \mathrm{M}$ $\mathrm{HNO}_{3}$ for strontium separation chemistry, following Pin and colleagues (1994). The separated strontium fraction was dried down, dissolved in $2 \mathrm{~mL} 0.2 \% \mathrm{HNO}_{3}$ and diluted to $200 \mathrm{ppb}$ strontium concentration prior to MC-ICP-MS isotope ratio analysis. Analyses of NIST SRM987 were used as a bracketing reference standard using a ${ }^{87} \mathrm{Sr} /{ }^{86} \mathrm{Sr}$ value of 0.710255 . The strontium isotope data was corrected for isobaric rubidium interference at $87 \mathrm{amu}$ using the measurement of ${ }^{85} \mathrm{Rb}$ and the natural ${ }^{85} \mathrm{Rb} /{ }^{87} \mathrm{Rb}$ ratio. Instrumental mass fractionation was corrected using the measured ${ }^{86} \mathrm{Sr} /{ }^{88} \mathrm{Sr}$ ratio, the exponential law, and a true ${ }^{86} \mathrm{Sr} /{ }^{88} \mathrm{Sr}$ ratio of 0.1194 . Analysis of an in-house carbonate reference material processed and measured with samples from this study $\quad\left({ }^{87} \mathrm{Sr} /{ }^{86} \mathrm{Sr}=0.708908 ; \quad 2 \sigma=0.000018\right)$ agreed well with long-term results $\left({ }^{87} \mathrm{Sr} /{ }^{86} \mathrm{Sr}=\right.$ $0.708911 ; 2 \sigma=0.000040, n=414)$.

\section{DNA Analysis}

Two independent DNA extractions were carried out at the ancient DNA research facilities of the Laboratoire AMIS CNRS UMR5288, Université de Toulouse III Paul Sabatier. DNA was extracted from 200 and $350 \mathrm{mg}$ of bone powder 
following method Y from Gamba and colleagues (2016), with the slight modifications from Gaunitz and colleagues (2018). Aliquots of DNA extracts were treated with the USER enzyme mix (NEB), following Librado and colleagues (2017), in order to reduce the impact of postmortem DNA damage in downstream analyses. Triple-indexed DNA libraries were constructed following the methodology from Fages and colleagues (2019), corresponding to the procedure described in Gaunitz and colleagues (2018) applied with the DNA adapters from Rohland and colleagues (2015; which include 7 bp long internal indexes). We amplified DNA libraries in $25 \mathrm{uL}$ reactions using the AccuPrime Pfx DNA polymerase following Gaunitz and colleagues (2018) before concentrating them using Agencourt bead purification, quantifying them on a TapeStation 4200 instrument (Agilent technologies), and pooling them together with other triple-indexed DNA libraries for sequencing on the Illumina MiniSeq. Sequencing reads were demultiplexed based on their internal adapter indexes using AdapterRemoval 2, allowing for a single nucleotide mismatch at best on each internal index, before they were parsed through PALEOMIX v1.2.13 with default parameters, except that seeding was disabled for BWA (Li and Durbin 2009) mapping (version $0.7 .17-r 1194$ ) in order to identify high-quality reads mapping uniquely against the horse nuclear reference genome EquCab2 and the horse mitochondrial genome (Accession \# NC_001640). The resulting read alignment files were then processed with the Zonkey package (Schubert et al. 2017) to identify first-generation equine hybrids and determine the molecular sex, merging the sequence data from both experiments (Supplemental Text 2).

\section{Results}

\section{Radiocarbon Dating}

AMS radiocarbon dating of dentin from the Lehi horse lower-right first molar returned a calibrated $2 \sigma$ range of $\mathrm{AD} 1681-1939\left(127 \pm 18{ }^{14} \mathrm{C} \mathrm{YBP}\right.$, OxA-38552), with a median date of AD 1838. The dentine $\mathrm{C} / \mathrm{N}$ ratio (3.2) and yield (9.5\%) fell within standard quality-control parameters, providing good support for the radiocarbon date. These results demonstrate that the Lehi horse is historic, not Pleistocene in age. Although narrowing the timing of the burial is challenging because of the multimodal calibrated probability distribution and shape of the calibration curve over this time period, the co-occurrence of the burial with a modified stone tool suggests that it predates permanent Mormon settlement in the region (ca. 1850) and may fall within the earlier half of this calibrated range.

\section{Osteological Study}

The morphology of the incisor grinding table (which lacks enamel spots on the lower but not the upper incisors), the fusion of all identified epiphyseal surfaces, and the crown height measurements of available cheek teeth suggest that the Lehi horse was approximately 12-13 years old at the time of death (Table 1), but it is important to note that the reliability of wear-based age estimates can be influenced by factors such as environment and diet (Allen 2008). Unfortunately, no relevant portions of the cranium or premolars were available for study. Although we identified no canines, the destruction of the cranium makes it impossible to ascribe the absence of these teeth in the recovered assemblage to sex. The presence of marked enamel hypoplasia on the available cheek teeth is far from uncommon in wild or domestic equids, but it indicates some degree of nutritional stress during the animal's lifetime.

We identified extreme levels of pathological bone formation on the vertebrae. This includes pathologic growth along the articular facets and ventral surface of vertebrae, particularly those of the lower back area most impacted by a seated rider (T16-18 and L1-L2), as well as irregular, undulating, transverse fractures of the caudal

Table 1. Crown Height Measurements Used to Assess Age of the Lehi Horse.

\begin{tabular}{lcc}
\hline Tooth & $\begin{array}{c}\text { Crown Height } \\
(\mathrm{mm})\end{array}$ & $\begin{array}{c}\text { Estimated Age Range } \\
\text { (Levine 1982) }\end{array}$ \\
\hline Upper right M1 & 39.91 & $12-13$ years \\
Lower right M1 & 46.42 & $12-13$ years \\
Lower left M1 & 45.06 & $12-13$ years \\
Lower left M2 & 47.97 & $12-13$ years \\
\hline
\end{tabular}


articular surface on T17 and T18 (Figure 4). Although much of the vertebral column was destroyed prior to excavation, we found impinging spinous processes on the $\mathrm{T} 13$ at the contact with both the T12 and T14.

The specimen exhibits extreme arthritis of the lower limbs and other pathologies that severely impacted its mobility (Holson 2018). The Lehi horse exhibits such severe arthritis of the right rear tibia and tarsal joint that the surface of the astragalus is deeply pitted, and most of the tarsals have fused into a single bony mass (Figure 6). In addition to this rear limb issue, the right radius/metacarpal joint of the forelimb is also impacted by arthritis, and the horse exhibits laminitis of the front left distal phalanx and a fracture to the medial splint bone (the left second metacarpal). These features may be related in that the immobility of the right rear joint may have caused conformation issues (laminitis) and compensation in the forelimbs, adding stress that caused a fracture of the splint bone. Pathological features identified through osteological analysis are summarized in Table 2.

\section{Isotope Analysis}

Sequential sampling of $\mathrm{M} 1 \delta^{13} \mathrm{C}(n=10)$ yielded an average value of $-10.4 \pm 0.6 \%$ with a $1.9 \%$ o range of -9.9 to $-11.8 \%$ (Table 3 ). Assuming a fractionation constant of $+13.8 \%$, as noted above (Cerling and Harris 1999), dietary forage $\delta^{13} \mathrm{C}$ ranged between -25.6 and $-23.7 \%$ with an average of $-24.2 \%$. Given a fractionation constant of approximately +14 , a protohistoric horse consuming $100 \% \quad \mathrm{C}_{3}$ vegetation would exhibit an enamel $\delta^{13} \mathrm{C}$ value of $c$. $-11 \%$, whereas a $100 \% \mathrm{C}_{4}$ diet would yield a carbonate $\delta^{13} \mathrm{C}$ value of approximately $+4 \%$ (Lee-Thorp 1989; Lee-Thorp et al. 1989; Levin et al. 2008). Estimates of reliance on $\mathrm{C}_{3}$ forage for the Lehi horse thus range between $100 \%$ and $91 \%$, averaging $94.6 \% \mathrm{C}_{3}$ intake. Average $\delta^{18} \mathrm{O}$ is $-11.7 \pm 0.4 \%$ o $(n=10)$ with a $1.3 \%$ range of -11.2 to $-12.5 \%$ o. $\delta^{13} \mathrm{C}$ and $\delta^{18} \mathrm{O}$ are inversely related, and both datasets suggest seasonal shifts

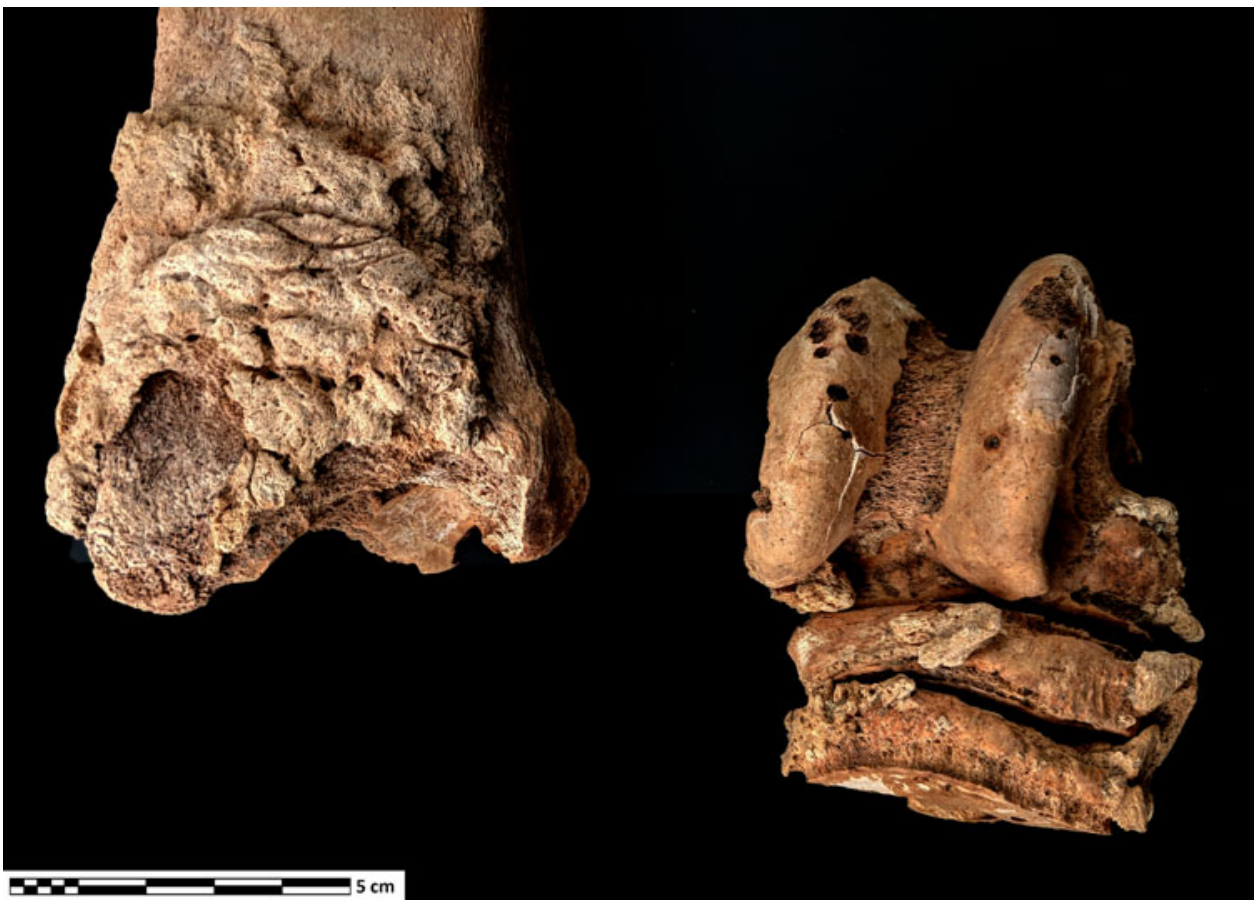

Figure 6. Examples of arthritic bone from the right hind leg. Severe arthritic bone formation and pitting of the posterior face of tibia (left) and the astragalus and tarsals (right), resulting in the complete immobility and fusion of many of the tarsal bones. (Color online) 
Table 2. Pathological Features Identified in the Lehi Horse.

\begin{tabular}{ll}
\hline Element & Pathological Features \\
\hline Dentition & Enamel hypoplasia \\
Lower back & Impinging dorsal spinous processes \\
(lower thoracic and lumbar vertebrae) & Transverse fractures of the caudal articular surface \\
& Bony exostoses (left biased) \\
Right rear limb (tibia/tarsals) & Arthritic pitting, eburnation, joint fusion \\
Front left limb (distal phalanx, second metacarpal) & Healed splint bone fracture \\
& Laminitis \\
\hline
\end{tabular}

Table 3. Normalized Stable Isotope Measurements and Standard Deviation for the Lehi Horse, as Sampled from the Lingual Surface of the Lower-Right First Molar.

\begin{tabular}{lccccccc}
\hline $\begin{array}{l}\text { Sample } \\
\text { Number }\end{array}$ & $\begin{array}{c}\text { Distance from } \\
\text { Root }(\mathrm{mm})\end{array}$ & $\begin{array}{c}\delta^{13} \mathrm{C} \% 0 \\
(\mathrm{VPDB})\end{array}$ & $\begin{array}{c}\text { Standard } \\
\text { Deviation }\end{array}$ & $\begin{array}{c}\delta^{18} \mathrm{O} \% \\
(\mathrm{VPDB})\end{array}$ & $\begin{array}{c}\text { Standard } \\
\text { Deviation }\end{array}$ & ${ }^{87} \mathrm{Sr} /{ }^{86} \mathrm{Sr}$ & $\begin{array}{c}\text { Estimated \% } \\
\mathrm{C}_{3}\end{array}$ \\
\hline 0 & 0 & -11.8 & 0.1 & -11.2 & 0.1 & 0.710526 & 100 \\
1 & 2 & -11.1 & 0.1 & -11.6 & 0.1 & - & 100 \\
2 & 4 & -10.3 & 0.1 & -11.7 & 0.1 & - & 94 \\
3 & 6 & -10.1 & 0.1 & -11.9 & 0.1 & - & 93 \\
4 & 8 & -10.0 & 0.1 & -12.0 & 0.1 & - & 92 \\
5 & 10 & -10.0 & 0.1 & -12.5 & 0.1 & 0.710570 & 92 \\
6 & 12 & -10.5 & 0.1 & -12.1 & 0.1 & - & 95 \\
7 & 14 & -10.6 & 0.1 & -11.7 & 0.1 & - & 96 \\
8 & 16 & -9.9 & 0.1 & -11.5 & 0.1 & - & 91 \\
9 & 18 & -10.1 & 0.1 & -11.3 & 0.1 & 0.710550 & 93 \\
\hline
\end{tabular}

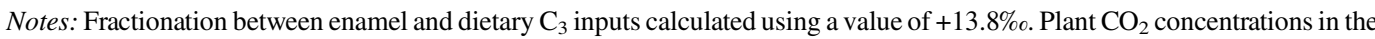
Lehi region during the late prehistoric period were $\sim 2.0 \%$ more positive than today (Dombrosky 2020).

in local forage and the temperature of imbibed water, respectively, across the period of enamel formation (Figure 7; Table 3). Strontium isotope values $(n=3$; Figure 7$)$ were consistent to the fourth decimal place (0.710526-0.710570) across the $18 \mathrm{~mm}$ sampled region (Figure 8), falling within an expected range for the greater Salt Lake region (Tipple et al. 2018) and in agreement with modern measured values from water sources in the Utah Lake region (Figure 1).

\section{DNA Analysis}

Combined, our two DNA extractions from the Lehi horse successfully yielded a total of 7,292 reads uniquely mapping to the reference mitochondrial and nuclear genomes of the domestic horse (E. caballus). The specimen yielded low but sufficient endogenous DNA to assess the sex, species, and first-generation hybrid status at virtually zero false-positive rates using the Zonkey pipeline (Schubert et al. 2017). These results provide clear indication that the animal is a domestic horse, E. caballus, and that the horse is female (Table 4).

\section{Discussion}

\section{Early Historic Indigenous Horse Riding and Herding in the Great Basin}

Our results provide conclusive evidence that the Lehi horse is early historic rather than Ice Age in origin, and that this animal was used for mounted horseback riding, likely by Native peoples during the eighteenth or early nineteenth centuries. Intact horse teeth have proven to be the most reliable and contamination-resistant biological material for dating archaeological horse remains (Zazzo et al. 2019), and our results place the Lehi horse burial between approximately 1680 and the early twentieth century. The recovery of flaked stone within the excavation points to an association with Indigenous cultures for the Lehi horse, and the deep overburden of sediment may have been generated by 


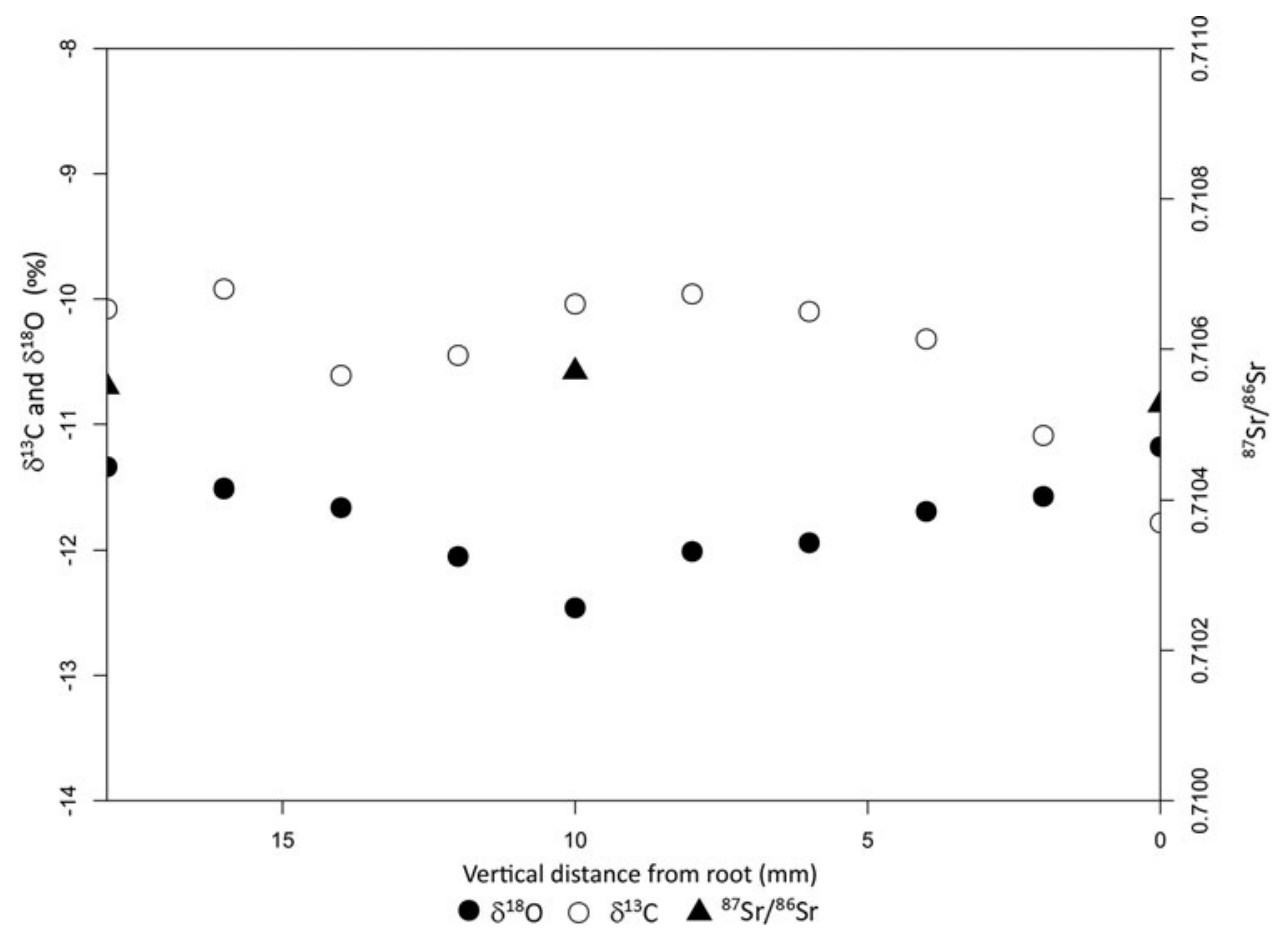

Figure 7. Normalized stable isotope measurements for stable oxygen (closed circle), carbon (open circle), and strontium (closed triangle) for the Lehi horse, as sampled from the lingual surface of the lower-right first molar.

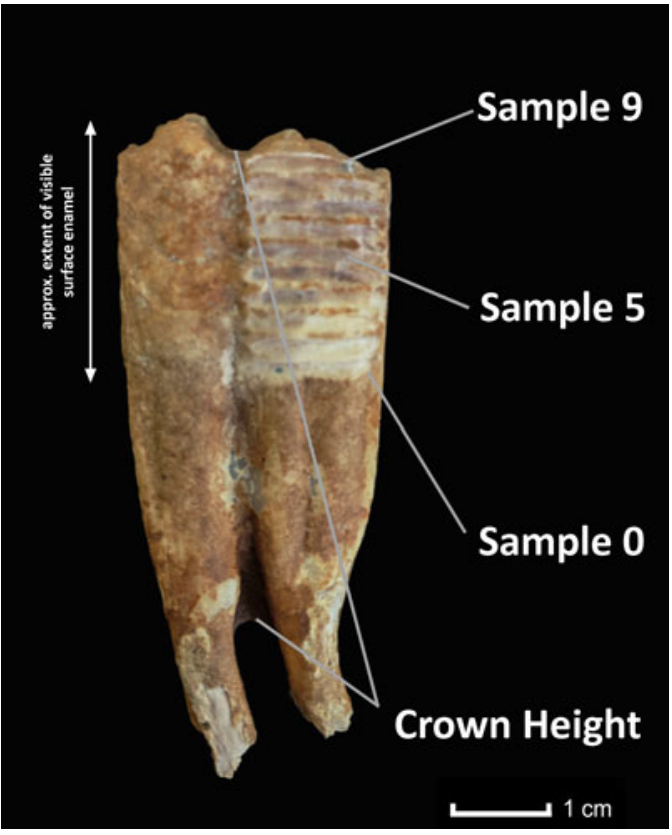

Figure 8. Lehi horse's lower right Molar 1, showing sample locations and location of crown height measurement. (Color online)
Euro-American farming and land-clearing activities after about 1850 (Morris and Rowe 2014). Based on ethnohistoric reconstructions, the area from which the Lehi horse was recovered would have straddled the boundary between Ute and Shoshone territory (Stewart 1970:209). The Northern Utah Ute acquired the horse as early as the seventeenth century, and they relied on it for their wide-ranging seasonal movements (Duncan 2003). The Shoshone obtained horses by the year 1700 , likely from the Ute, and they played a major role in funneling horses to the northern Plains and Plateau (Mitchell 2015). Although our data do not allow us to determine whether this particular horse belonged to the Ute, the Shoshone, or both, our results do articulate with the ethnohistory of the region, given that the horse had become critically important to both Ute and Shoshone societies by the eighteenth century.

Analysis of the animal's skeleton demonstrates that the horse was ridden, and it reveals health issues that imply a degree of human 
Table 4. Genetic Identification of Species and Sex of the Lehi Horse.

\begin{tabular}{|c|c|c|c|c|c|c|c|}
\hline Specimen & $\begin{array}{l}\text { Endogenous } \\
\text { DNA Content } \\
(\%)\end{array}$ & $\begin{array}{l}\text { Mitochondrial } \\
\text { Fold Coverage }\end{array}$ & $\begin{array}{c}\text { Total } \\
\text { Number of } \\
\text { Reads } \\
\text { Sequenced }\end{array}$ & $\begin{array}{l}\text { Reads } \\
\text { Uniquely } \\
\text { Mapping to } \\
\text { Nuclear } \\
\text { Reference }\end{array}$ & $\begin{array}{l}\text { Reads Uniquely } \\
\text { Mapping to } \\
\text { Mitochondrial } \\
\text { References }\end{array}$ & Species & Sex \\
\hline $\begin{array}{l}\text { AMIS_1_01735, } \\
\text { combined }\end{array}$ & 0.41 & 0.2439 & $1,781,440$ & 7,292 & 63 & & $\begin{array}{l}\stackrel{+}{\text { Femal }} \\
\end{array}$ \\
\hline & & & & & & E. caballu & \\
\hline $\begin{array}{c}\text { AMIS_1_01735, } \\
\text { extraction } 1\end{array}$ & 0.32 & 0.0226 & 907,645 & 2,904 & 6 & - & - \\
\hline $\begin{array}{c}\text { AMIS_1_01735, } \\
\text { extraction } 2\end{array}$ & 0.51 & 0.2213 & 873,795 & 4,388 & 57 & - & - \\
\hline
\end{tabular}

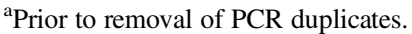

protection or care. Damage to the vertebrae of the lower back-osteophytes, impinging spinous processes, and transverse fractures of the caudal articular surface-is characteristically associated with mounted riding, and it is generally absent from wild animals (Levine 1999; Levine et al. 2005). Although this type of damage is found in many ancient assemblages linked to horseback riding, it is particularly pronounced among archaeological horses predating the innovation of the frame saddle because riding bareback entails more direct trauma to the vertebral column (Levine et al. 2005). Among those vertebrae that yielded osteophytes and new bone formation (T5, T13, and T16-L2), this bone growth was universally asymmetric, in favor of more developed bone spurs on the animal's left side (Figure 9). We have identified similarly pronounced asymmetry in ridden-horse assemblages from Eurasia (Li et al. 2020). Asymmetric bias in equine skeletal damage may be related to rider handedness or riding technique (Taylor and Tuvshinjargal 2018), but it could also be influenced by consistent mounting from one side. Previously identified vertebral asymmetry in East Asian assemblages is clearly left biased (Levine et al. 2005; Li et al. 2020). Although many Native American horsemen are known historically to have mounted from the right side, it may be that this difference in weight bearing is caused by the handedness of the rider and the dynamics of mounted activities.

The pattern of pathological damage to the lower back observed in the Lehi horse clearly indicates that the animal was used for riding.
Archaeological assemblages of animals used only for chariot traction, for example, show increased pathology in the forelimbs and neck region but little damage to the thoracic or lumbar vertebrae (Levine 2005; Weber 2008). This observation does not rule out the animal's use for other purposes, however. Many Native American groups in western North America employed horses for pack transport (Ewers 1955), either with or without a travois (a polebased sledge system adapted from existing technology used for dog transport). This system could be, and often was, used in tandem with a saddle and rider, which could have produced an osteological signature similar to that observed in the Lehi horse.

Extreme arthritis and other bone pathologies in the animal's limbs provide further evidence of its use in transport. The fusion of most of the bones of the lower joint of the right rear limb would have given this horse extreme difficulty in movement. Any horse-wild or domestic-can suffer from these maladies, which are likely to limit an animal's mobility severely. In the Lehi horse, these pathologies are severe, and they imply that the horse must have been cared for, or at least intentionally retained, even after reaching levels of impaired mobility. The issues with this joint may have radiated throughout the body as the animal experienced continued use. The horse also developed laminitis in a front hoof and fractured a splint bone, both potentially caused by compensation for the impaired hoof. These features suggest that, despite lameness, 


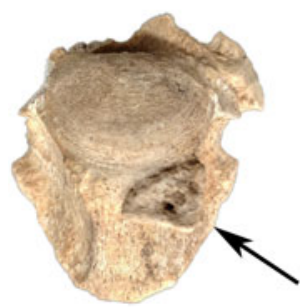

T5

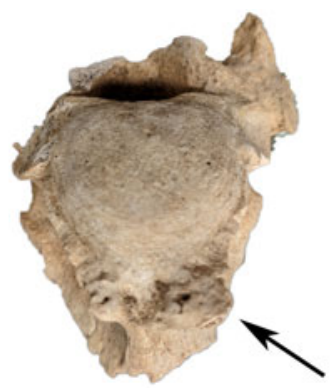

T13

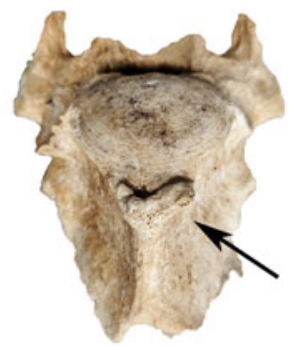

T16
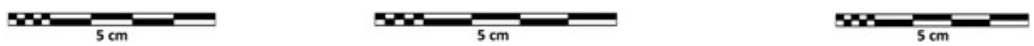

Figure 9. Arrows indicate bony exostoses on the ventrolateral surfaces of vertebrae from the Lehi horse, showing asymmetric bone formation on the animal's left side in all cases. Thoracic vertebrae 5 (left), 13 (center), and 16 (right). All in ventrocranial view. (Color online)

the Lehi horse continued to be ridden (or perhaps used in transport in other ways, such as pulling loads in a travois). Indeed, the age of 12 seems remarkably young for a horse to have developed the observed level of pathology through natural aging processes. We argue that one of the only ways an animal with such severe mobility issues could have survived without dying from predation or starvation would be through human management or care.

The genomic identification of the Lehi horse as the domestic E. caballus and its identification as a female support its identification as a pastorally managed horse. Although the animal's injuries would have drastically reduced its usefulness in transport, female horses continue to produce young annually until around 15 years of age (Garrott et al. 1991). As a result, archaeological assemblages related to pastorally managed breeding herds of horses rarely yield breeding-age females. Instead, they consist largely of elderly females (along with young males, who are culled before reaching breeding age; Levine 1999; Taylor 2017). The advanced age of the Lehi horse, and the co-occurrence of mobility-restricting pathological issues in the limbs suggest that the mare was either retained as a breeding animal until she died or that she was culled/sacrificed after reaching the end of her reproductive viability.

\section{Mobility and Movement}

Our lower stable oxygen isotope values likely correspond to a single, late-spring snow melt event, bracketed by slightly elevated $\delta^{18} \mathrm{O}$ values characteristic of lower-elevation precipitation, during the Lehi horse's second year of life (Figures 4 and 7; Table 3). The lowest Lehi horse $\delta^{18} \mathrm{O}$ reading is paired with the highest $\delta^{13} \mathrm{C}$ value, and $\delta^{13} \mathrm{C}$ is loosely inversely related with $\delta^{18} \mathrm{O}$ across all but the last two samples taken at $16 \mathrm{~mm}$ and $18 \mathrm{~mm}$ from the enamel base. These data indicate a slight shift in the type of forage relied upon through winter into late spring-perhaps an increase in consumption of $\mathrm{C}_{4}$ forbs beginning to green up in mid-spring, incrementally increasing the stable carbon isotope values of the Lehi horse. De Winter and colleagues (2016) also found a similar pattern of higher $\delta^{13} \mathrm{C}$ values with winter $\delta^{18} \mathrm{O}$ values in modern horses in Europe, which may be attributable to changes in plant water use efficiency or slight variations in plant choices during the winter season. Maize, also a $\mathrm{C}_{4}$ domesticate, was farmed by prehistoric Fremont groups along the eastern rim of the Great Basin, but maize agriculture was abandoned by approximately AD 1150 in the Utah and Great Salt Lake Valleys, coincident with the end of the Medieval Climate Anomaly (Coltrain and Leavitt 2002). Prior to pioneer settlement in 1847 , maize was not cultivated by indigenous Ute or Shoshone populations. Thus, foddering with maize is unlikely to have made a significant contribution to the Lehi horse's very slightly elevated spring $\delta^{13} \mathrm{C}$ values.

Historically, the Ute are known to have made fall and winter seasonal movements between 
low-elevation wintering grounds and highelevation summer hunting grounds, as well as between territories to the south and east, ranging as far as eastern Colorado and western Kansas, and hunting in New Mexico, Arizona, and the Texas and Oklahoma panhandles. It is possible that Indigenous pastoralism of equids included moving herds south from Utah Valley during winter months, but neither strontium nor stable oxygen isotope values for the Lehi horse support this interpretation for this particular individual. Strontium signatures do not vary seasonally, but they are consistent at the fourth decimal place (0.710526-0.710570). Moreover, all observed values fall within an expected range for the greater Salt Lake region (Tipple et al. 2018), providing no evidence that carbon and oxygen isotope patterning was the consequence of nonlocal movement.

\section{Conclusion}

Our results demonstrate that the Lehi horse is indeed an early historic domestic horse, likely managed and used by Indigenous people. Osteological pathologies indicate that the Lehi horse was ridden, perhaps bareback or using a soft pad saddle. The animal's use continued even after it developed issues with the right rear limb, which caused ancillary effects in other limbs-including arthritis, a fracture, and laminitis. Pathological bone growths on the vertebrae suggest that the horse experienced consistently higher loads on its left-hand side, a pattern that is known from other archaeological assemblages and is characteristic of ridden horses. DNA confirms the identification of the Lehi horse as Equus caballus, not an Ice Age wild equid, and reveals that the animal was a mare. This is consistent with expectations for a pastorally managed herd animal, and it explains the apparent care for the horse into advanced age despite severe mobility issues. Stable isotopes sampled from the horse's enamel point to seasonal shifts in the isotope chemistry of imbibed water and available vegetation, which-in tandem with minimal variance in strontium isotope-suggests that the horse was raised and tended locally within the Wasatch Front near where it was found.
This study provides an example of how to engage data quality in zooarchaeology (e.g., Wolverton 2013) as well as a template for the integration of morphological and biomolecular approaches (Steele 2015)—subjects that have been a key focus of discussion in archaeozoological circles in recent years (e.g., Jones and Gabe 2015; Kansa et al. 2019; LeFebvre et al. 2019; Nims and Butler 2019). Our identification of the Lehi horse as an early domestic rather than an Ice Age horse suggests that prior misclassifications may have influenced museum collection practices and the interpretation of archaeological and paleontological assemblages, leading to gaps in the faunal record of Native horsemanship. Consequently, the reevaluation of horse skeletons in natural history collections, focusing on both osteological markers of human activity and biomolecular analyses, appears warranted-and such studies may significantly change our understanding of the timing and nature of early Indigenous horse use in the Americas.

Acknowledgments. This research was funded by an award from the National Science Foundation (Horses and Human Societies in the American West, Award \#1949305). Additional osteological and isotopic research was funded by the Max Planck Institute for the Science of Human History, with supplementary funding by the Haus der Kulturen der Welt "Mississippi: An Anthropocene River" project. Special thanks to the Hill Family for reporting the discovery of the specimen and to Dr. Juan Bautista Belardi for translating the Spanish language version of the abstract. This project also received funding from the European Research Council (ERC) under the European Union's Horizon 2020 research and innovation program (grant agreement No. 681605).

Data Availability Statement. All data collected during this research are provided in the manuscript and supplemental materials.

Supplemental Materials. For supplemental material accompanying this article, visit https://doi.org/10.1017/aaq.2020.109.

Supplemental Text 1. Lehi Horse Stratigraphic Description.

Supplemental Text 2. Zonkey Analysis Report.

Supplemental Figure 1. Horse burial from the early seventeenth-century Saxman site in Kansas, informally excavated and disposed of during the 1970s, on the assumption that it was modern.

Supplemental Figure 2. Still photo from a video recorded during excavation; photos of the subsurface stratigraphy during excavation; photos of the subsurface stratigraphy directly adjacent to the horse remains during excavation. 


\section{References Cited}

Allen, Tom

2008 Manual of Equine Dentistry. Muleicorn Press, New York.

Anthony, David, Dimitri Y. Telegin, and Dorcas Brown

1991 The Origin of Horseback Riding. Scientific American 265(6):94-101.

Balasse, Marie

2002 Reconstructing Dietary and Environmental History from Enamel Isotopic Analysis: Time Resolution of Intra-Tooth Sequential Sampling. International Journal of Osteoarchaeology 12:155-165.

Bartosiewicz, László, and Erika Gal

2013 Shuffling Nags, Lame Ducks: The Archaeology of Animal Disease. Oxbow Books, Oxford.

Bendrey, Robin

2007 New Methods for the Identification of Evidence for Bitting on Horse Remains from Archaeological Sites. Journal of Archaeological Science 34:1036-1050.

2008 An Analysis of Factors Affecting the Development of an Equine Cranial Enthesopathy. Veterinarija ir Zootechnika 41(63):25-31.

Bendrey, Robin, T. E. Hayes, and M. R. Palmer

2009 Patterns of Iron Age Horse Supply: An Analysis of Strontium Isotope Ratios in Teeth. Archaeometry 51:140-150.

Benson, Larry, Stephen Lund, Joseph Smoot, Davide Rhode, R. J. Spencer, Kenneth Verosub, Lisbeth Louderback, Craig A. Johnson, Robert O. Rye, and Robert Negrini

2011 The Rise and Fall of Lake Bonneville Between 45 and 10.5 ka. Quaternary International 235:57-69.

Biek, Robert

2005 Geologic Map of the Lehi Quadrangle and Part of the Timpanogos Cave Quadrangle, Salt Lake and Utah Counties, Utah. Utah Geological Survey, Salt Lake City, Utah.

Bourgeon, Lauriane, Ariane Burke, and Thomas Higham

2017 Earliest Human Presence in North America Dated to the Last Glacial Maximum: New Radiocarbon Dates from Bluefish Caves, Canada. PLoS ONE 12(1): e0169486. DOI:10.1371/journal.pone.0169486.

Brock, Fiona, Thomas Higham, Peter Ditchfield, and Christopher Bronk Ramsey

2010 Current Pretreatment Methods for AMS Radiocarbon Dating at the Oxford Radiocarbon Accelerator Unit (Orau). Radiocarbon 52:103-112.

Capo, Rosemary C., Brian W. Stewart, and Oliver A. Chadwick

1998 Strontium Isotopes as Tracers of Ecosystem Processes: Theory and Methods. Geoderma 82:197-225.

Cerling, Thure, and John Harris

1999 Carbon Isotope Fractionation between Diet and Bioapatite in Ungulate Mammals and Implications for Ecological and Paleoecological Studies. Oecologia 120:347-363.

Cerling, Thure, John Harris, Meave Leakey, Benjamin Passey, and Naomi Levin

2010 Stable Carbon and Oxygen Isotopes in East African Mammals: Modern and Fossil. In Cenozoic Mammals of Africa, edited by Lars Werdelin and William Joseph Sanders, pp. 949-960. University of California Press, Berkeley.

Coltrain, Joan, and Steven Leavitt

2002 Climate and Diet in Fremont Prehistory: Economic Variability and Abandonment of Maize Agriculture in the Great Salt Lake Basin. American Antiquity 67:453-485.

Copeland, Sandi R., Matt Sponheimer, Petrus J. le Roux, Vaughan Grimes, Julia A. Lee-Thorp, Darryl J. de Ruiter, and Michael P. Richards

2008 Strontium Isotope Ratios $(87 \mathrm{Sr} / 86 \mathrm{Sr})$ of Tooth Enamel: A Comparison of Solution and Laser Ablation Multicollector Inductively Coupled Plasma Mass Spectrometry Methods. Rapid Communications in Mass Spectrometry 22:3187-3194.

Coplen, Tyler B., and Carol Kendall

2000 Stable Hydrogen and Oxygen Isotope Ratios for Selected Sites of the U.S. Geological Survey's NASQAN and Benchmark Surface-Water Networks. U.S. Geological Survey Open-File Report 00-160.

Cotton, Jennifer, Thure Cerling, Kathryn Hoppe, Thomas Mosier, and Christopher Still

2016 Climate, CO2 and the History of North American Grasses since the Last Glacial Maximum. Science Advances 2(3). DOI:10.1126/sciadv.1501346.

Dansgaard, Willi

1964 Stable Isotopes in Precipitation. Tellus 16:436-468.

Daux, Valérie, Christophe LéCuyer, Frédéric Adam, François Martineau, and Françoise Vimeux

2005 Oxygen Isotope Composition of Human Teeth and the Record of Climate Changes in France (Lorraine) during the Last 1,700 Years. Climatic Change 70:445-464.

de Winter, Niels, Christophe Snoeck, and Philippe Claeys

2016 Seasonal Cyclicity in Trace Elements and Stable Isotopes of Modern Horse Enamel. PLoS ONE 11(11): e0166678. DOI:10.1371/journal.pone.0166678.

Dombrosky, Jonathan

2020 A 1000-Year ${ }^{13} \mathrm{C}$ Suess Correction Model for the Study of Past Ecosystems. Holocene 30:474-478.

Duncan, Clifford

2003 The Northern Utes of Utah. In History of Utah's American Indians, edited by Forrest Cuch, pp. 167224. Utah State University Press, Logan.

Eckles, David, Jeffrey Lockwood, Rabinder Kumar, Dale Wedel, and Danny Walker

1994 An Early Historic Period Horse Skeleton from Southwestern Wyoming. Wyoming Archaeologist 38(3-4):55-68.

Ehleringer, James R.

1989 Carbon Isotope Ratios and Physiological Processes in Aridland Plants. In Stable Isotopes in Ecological Research, edited by Phillip Rundel, James Ehleringer, and Kenneth Nagy, pp. 41-54. Springer, New York.

Evans, Patricia, Nancy Jack, Dorothy E. King, and Steve Jones

2006 Aging Horses by Their Teeth. University of Arkansas Division of Agriculture, Fayetteville.

Ewers, John C.

1955 The Horse in Blackfoot Indian Culture: With Comparative Material from Other Western Tribes. Smithsonian Institution, Washington, DC.

Fages, Antoine, Kristian Hanghoej, Naveed Khan, Charleen Gaunitz, Andaine Seguin-Orlando, Michela Leonardi, Christian McCrory Contantz, Cristina Gamba, Khaled Al-Rasheid, Sylvia Albizuri, Ahmed Alfarhan, Morten Allentoft, Saleh Alquraishi, David Anthony, Norbert Benecke, Eloisa Bernáldez Sánchez, Luis Berrocal-Rangel, Fereidoun Biglari, Sanne Boessenkoo, Bazartseren Boldgiv, Gottfried Brem, Dorcas Brown, Joachim Burger, Eric Crubéz, 
Linas Daugnora, Hossein Davoudi, Peter de Barros Damgaard, Maríade los Ángeles de Chorro y de VillaCeballos, Sabine Deschler-Erb, Cleia Detry, Nadine Dill, Mariado Mar Oom, Anna Dohr, Sturla Ellingvåg, Diimaajav Erdenebaatar, Homa Fathi, Sabine Felkel, Carlos Fernández-Rodríguez, Esteban García-Viñas, Mietje Germonpré, José D. Granado, Jón H. Hallsson, Helmut Hemmer, Michael Hofreiter, Aleksei Kasparov, Mutalib Khasanov, Roya Khazaeli, Pavel Kosintsev, Kristian Kristiansen, Tabaldiev Kubatbek, Lukas Kuderna, Pavel Kuznetsov, Haeedeh Laleh, Jennifer A. Leonard, Johanna Lhuillier, Corina Liesau von Lettow-Vorbeck, Andrey Logvin, Lembi Lõugas, Arne Ludwig, Cristina Luis, Ana Margarida Arruda, Tomas Marques-Bonet, Raquel Matoso Silva, Victor Merz, Enkhbayar Mijiddorj, Bryan K. Miller, Oleg Monchalov, Fatemeh Mohaseb, Arturo Morales, Ariadna Nieto-Espinet, Heidi Nistelberger, Vedat Onar, Albína H. Pálsdóttir, Vladimir Pitulko, Konstantin Pitskhelauri, Mélanie Pruvost, Petra Rajic Sikanjic, Anita Rapan Papeša, Natalia Roslyakova, Alireza Sardari, Eberhard Sauer, Renate Schafberg, Amelie Scheu, Jörg Schibler, Angela Schlumbaum, Nathalie Serrand, Aitor SerresArmero, Beth Shapiro, Shiva Sheikhi Seno, Irina Shevnina, Sonia Shidrang, John Southon, Bastiaan Star, Naomi Sykes, Kamal Taheri, William Taylor, WolfRüdiger Teegen, Tajana Trbojević Vukičević, Simon Trixl, Dashzeveg Tumen, Sainbileg Undrakhbold, Emma Usmanova, Ali Vahdati, Silvia ValenzuelaLamas, Catarina Viegas, Barbara Wallner, Jaco Weinstock, Victor Zaibert, Benoit Clavel, Sébastien Lepetz, Marjan Mashkour, Agnar Helgason, Kári Stefánsson, Eric Barrey, Eske Willerslev, Alan K. Outram, Pablo Librado, and Ludovic Orlando

2019 Tracking Five Millennia of Horse Management with Extensive Ancient Genome Time Series. Cell 177:1419-1435.

Farquhar, G. D., J. R. Ehleringer, and K. T. Hubick

1989 Carbon Isotope Discrimination and Photosynthesis. Annual Review of Plant Physiology and Plant Molecular Biology 40:503-537.

Fricke, Henry C., and James R. O'Neil

1999 The Correlation between ${ }^{18} \mathrm{O} /{ }^{16} \mathrm{O}$ Ratios of Meteoric Water and Surface Temperature: Its Use in Investigating Terrestrial Climate Change over Geologic Time. Earth and Planetary Science Letters 170:181-196.

Gamba, Cristina, Kristian Hanghøj, Charleen Gaunitz, Ahmed H. Alfarhan, Saleh A. Alquraishi, Khaled A. S. Al-Rasheid, Daniel G. Bradley, and Ludovic Orlando

2016 Comparing the Performance of Three Ancient DNA Extraction Methods for High-Throughput Sequencing. Molecular Ecology Resources 16:459-469.

Garrott, Robert, Thomas Eagle, and Edward Plotka

1991 Age-Specific Reproduction in Feral Horses. Canadian Journal of Zoology 69:738-743. DOI:10.1139/ z91-106.

Gaunitz, Charleen, Antoine Fages, Kristian Hanghøj, Anders Albrechtsen, Naveed Khan, Mikkel Schubert, Andaine Seguin-Orlando, Ivy J. Owens, Sabine Felkel, Olivier Bignon-Lau, Peter de Barros Damgaard, Alissa Mittnik, Azadeh F. Mohaseb, Hossein Davoudi, Saleh Alquraishi, Ahmed H. Alfarhan, Khaled A. S. Al-Rasheid, Eric Crubézy, Norbert Benecke, Sandra Olsen, Dorcas Brown, David Anthony, Ken Massy Vladimir Pitulko, Aleksei Kasparov, Gottfried Brem, Michael Hofreiter,
Gulmira Mukhtarova, Nurbol Baimukhanov, Lembi Lõugas, Vedat Onar, Philipp W. Stockhammer, Johannes Krause, Bazartseren Boldgiv, Sainbileg Undrakhbold, Diimaajav Erdenebaatar, Sébastien Lepetz, Marjan Mashkour, Arne Ludwig, Barbara Wallner, Victor Merz, Ilja Merz, Viktor Zaibert, Eske Willerslev, Pablo Librado, Alan K. Outram, and Ludovic Orlando

2018 Ancient Genomes Revisit the Ancestry of Domestic and Przewalski's Horses. Science 360:111-114. DOI:10.1126/science.aao3297.

Graustein, William, and Richard Armstrong

1983 The Use of Strontium-87/Strontium-86 Ratios to Measure Atmospheric Transport into Forested Watersheds. Science 219:289-292.

Haile, James, Duane G. Froese, Ross D. E. MacPhee, Richard G. Roberts, Lee J. Arnold, Alberto V. Reyes, Morten Rasmussen, Rasmus Nielsen, Barry W. Brook, Simon Robinson, Martina Demuro, M. Thomas P. Gilbert, Kasper Munch, Jeremy J. Austin, Alan Cooper, Ian Barnes, Per Möller, and Eske Willerslev

2009 Ancient DNA Reveals Late Survival of Mammoth and Horse in Interior Alaska. PNAS 106:22352-22357.

Hämäläinen, Pekka

2008 The Comanche Empire. Yale University Press, New Haven, Connecticut.

Hamilton, Marian I., B. Lee Drake, W. H. Wills, Emily Lena Jones, Cyler Conrad, and Patricia L. Crown

2018 Stable Oxygen Isotope Sourcing of Archaeological Fauna from Chaco Canyon, New Mexico. American Antiquity 83:163-175.

Heintzman, Peter D., Grant D. Zazula, Ross D. E. MacPhee, Eric Scott, James A. Cahill, Brianna K. McHorse, Joshua D. Kapp, Mathias Stiller, Matthew J. Wooller, Ludovic Orlando, John Southon, Duane G. Froese, and Beth Shapiro

2017 A New Genus of Horse From Pleistocene North America. eLife 6. DOI:10.7554/eLife.29944.

Hintze, Lehi, Grant Willis, Denise Laes, Douglas Sprinkel, and Kent Brown

2000 Digital Geologic Map of Utah: Utah Geological Survey Map 179DM. Scale 1(500,000). Utah Geological Survey, Salt Lake City, Utah.

Holson, Laura M.

2018 An Ancient Horse Is Unearthed in a Utah Backyard. New York Times, May 3. https://www.nytimes.com/ 2018/05/03/science/horse-skeleton-utah.html, accessed January 19, 2020.

Hoppe, Kathryn A., Susan M. Stover, John R. Pascoe, and Ronald Amundson

2004 Tooth Enamel Biomineralization in Extant Horses: Implications for Isotopic Microsampling. Palaeogeography, Palaeoclimatology, Palaeoecology 206:355365.

Jones, Emily Lena, and Caroline Gabe

2015 The Promise and Peril of Older Collections: Meta-Analyses and the Zooarchaeology of Late Prehistoric/Early Historic New Mexico. Open Quaternary 1 (1):p.Art. 6. DOI:10.5334/oq.ag.

Kansa, Sarah W., Levent Atici, Eric C. Kansa, and Richard H. Meadow

2019 Archaeological Analysis in the Information Age: Guidelines for Maximizing the Reach, Comprehensiveness, and Longevity of Data. Advances in Archaeological Practice 8:40-52

Kooyman, B., L. V. Hills, P. McNeil, and S. Tolman

2006 Late Pleistocene Horse Hunting at the Wally's 
Beach Site (DhPg-8), Canada. American Antiquity 71:101-121.

Lee-Thorp, Julia Anne

1989 Stable Carbon Isotopes in Deep Time: The Diets of Fossil Fauna and Hominids. PhD dissertation, Department of Archaeology, Open UCT, University of Cape Town, Cape Town, South Africa.

Lee-Thorp, Julia, Andossa Likius, Hassane T. Mackaye, Patrick Vignaud, Matt Sponheimer, and Michel Brunet

2012 Isotopic Evidence for an Early Shift to $\mathrm{C}_{4}$ Resources by Pliocene Hominins in Chad. PNAS 109:2036920372.

Lee-Thorp, Julia A., Judith C. Sealy, and Nikolaas J. van der Merwe

1989 Stable Carbon Isotope Ratio Differences between Bone Collagen and Bone Apatite, and Their Relationship to Diet. Journal of Archaeological Science 16:585-599.

Lee, Joon Sang

2010 Stomatal Opening Mechanism of CAM Plants. Journal of Plant Biology 53:19-23.

LeFebvre, Michelle J., Laura Brenskelle, John Wieczorek, Sarah Whitcher Kansa, Eric C. Kansa, Neill J. Wallis, Jessica N. King, Kitty F. Emery, and Robert Guralnick

2019 ZooArchNet: Connecting Zooarchaeological Specimens to The Biodiversity and Archaeology Data Networks. PLoS ONE 14(4):e0215369. DOI:10.1371/ journal.pone.0215369.

Levin, Naomi E., Thure E. Cerling, Benjamin H. Passey, John M. Harris, and James R. Ehleringer

2006 A Stable Isotope Aridity Index for Terrestrial Environments. PNAS 103:11201-11205.

Levin, Naomi E., Scott W. Simpson, Jay Quade, Thure E. Cerling, and Stephen R. Frost

2008 Herbivore Enamel Carbon Isotopic Composition and the Environmental Context of Ardipithecus at Gona, Ethiopia. Geology of Early Humans in the Horn of Africa 446:215-234.

Levine, Marsha A.

1982 The Use of Crown Height Measurements and Eruption-Wear Sequences to Age Horse Teeth. In Ageing and Sexing Animal Bones from Archaeological Sites, edited by Bob Wilson, Caroline Grigson, and Sebastian Payne, pp. 223-250. British Archaeological Reports, Oxford.

1999 The Origins of Horse Husbandry on the Eurasian Steppe. In Late Prehistoric Exploitation of the Eurasian Steppe, edited by Marsha Levine, Yuri Rassamakin, Aleksandr Kislenko, and Nataliya Tatarintseva, pp. 558. McDonald Institute for Archaeological Research, Oxford.

2005 Chinese Chariot Horses and the Evolution of Horse Husbandry. McDonald Institute for Archaeological Research. Electronic document, https://www.arch.cam. ac.uk/ ml12/ChinPalaeoWebsite/introduction.htm, accessed May 15, 2010.

Levine, Marsha A., Katherine E. Whitwell, and Leo B. Jeffcott

2005 Abnormal Thoracic Vertebrae and the Evolution of Horse Husbandry. Archaeofauna 14:93-109.

Li, Heng, and Richard Durbin

2009 Fast and Accurate Short Read Alignment with Burrows- Wheeler Transform. Bioinformatics 25:1754 1760.

Li, Yue, Chengrui Zhang, William Taylor, Liang Chen, Rowan Flad, Nicole Boivin, Jianxin Wang, Huan Liu,
Yue You, Meng Ren, Tongyuan Xi, Yifu Han, Rui Wen, and Jian Ma

2020 Early Evidence for Mounted Horseback Riding in Northwest China. PNAS 117:29569-29576.

Librado, Pablo, Cristina Gamba, Charleen Gaunitz, Clio Der Sarkissian, Mélanie Pruvost, Anders Albrechtsen, Antoine Fages, Naveed Khan, Mikkel Schubert, Vidhya Jagannathan, Aitor Serres-Armero, Lukas F. K. Kuderna, Inna S. Povolotskaya, Andaine SeguinOrlando, Sébastien Lepetz, Markus Neuditschko, Catherine Thèves, Saleh Alquraishi, Ahmed H. Alfarhan, Khaled Al-Rasheid, Stefan Rieder, Zainolla Samashev, Henri-Paul Francfort, Norbert Benecke, Michael Hofreiter, Arne Ludwig, Christine Keyser, Tomas Marques-Bonet, Bertrand Ludes, Eric Crubéz, Tosso Leeb, Eske Willerslev, and Ludovic Orlando

2017 Ancient Genomic Changes Associated with Domestication of the Horse. Science 356:442-445.

Makarewicz, Cheryl A., Christine Winter-Schuh, Heather Byerly, and Jean-Luc Houle

2018 Isotopic Evidence for Ceremonial Provisioning of Late Bronze Age Khirigsuurs with Horses from Diverse Geographic Locales. Quaternary International 476:70-81.

Milligan, Mark, and H. Gregory McDonald

2017 Shorelines and Vertebrate Fauna of Pleistocene Lake Bonneville, Utah, Idaho, and Nevada. Geology of the Intermountain West 4:181-214.

Mitchell, Peter

2015 Horse Nations: The Worldwide Impact of the Horse on Indigenous Societies Post-1492. Oxford University Press, Oxford.

Montgomery, Janet

2010 Passports from the Past: Investigating Human Dispersals Using Strontium Isotope Analysis of Tooth Enamel. Annals of Human Biology 37:325-346.

Morris, Lesley R., and Rebecca J. Rowe

2014 Historical Land Use and Altered Habitats in the Great Basin. Journal of Mammalogy 95:1144-1156.

Nelson, Michael, and James Madsen Jr

1987. A Review of Lake Bonneville Shoreline Faunas (Late Pleistocene) of Northern Utah. In Cenozoic Geology of Western Utah-Sites for Precious Metal and Hydrocarbon Accumulations, edited by Richard Kopp and Robert Cohenour, pp. 319-333. Publication 16. Utah Geological Association, Salt Lake City, Utah.

Nims, Reno, and Virginia L. Butler

2019 Increasing the Robustness of Meta-Analysis through Life History and Middle-Range Models: An Example from the Northeast Pacific. Journal of Archaeological Method and Theory 26:581-618.

Notaro, Michael, Zhengyu Liu, Robert G. Gallimore, John W. Williams, David S. Gutzler, and Scott Collins

2010 Complex Seasonal Cycle of Ecohydrology in the Southwest United States. Journal of Geophysical Research: Biogeosciences 115:403.

Orlando, Ludovic, Aurélien Ginolhac, Guojie Zhang, Duane Froese, Anders Albrechtsen, Mathias Stiller, Schubert, Enrico Cappellini, Bent Petersen, Ida Moltke, Philip L. F. Johnson, Matteo Fumagalli, Julia T. Vilstrup, Maanasa Raghavan, Thorfinn Korneliussen, Anna-Sapfo Malaspinas, Josef Vogt, Damian Szklarczyk, Christian D. Kelstrup, Jakob Vinther, Andrei Dolocan, Jesper Stenderup, Amhed M. V. Velazquez, James Cahill, Morten Rasmussen, Xiaoli Wang, Jiumeng Min, Grant D. Zazula, Andaine Seguin-Orlando, Cecilie Mortensen, Kim Magnussen, John F. Thompson, 
Jacobo Weinstock, Kristian Gregersen, Knut H. Røed, Véra Eisenmann, Carl J. Rubin, Donald C. Miller, Douglas F. Antczak, Mads F. Bertelsen, Søren Brunak, Khaled A. S. Al-Rasheid, Oliver Ryder, Leif Andersson, John Mundy, Anders Krogh, M. Thomas P. Gilbert, Kurt Kjær, Thomas Sicheritz-Ponten, Lars Juhl Jensen, Jesper V. Olsen, Michael Hofreiter, Rasmus Nielsen, Beth Shapiro, Jun Wang, and Eske Willerslev

2013 Recalibrating Equus Evolution Using the Genome Sequence of an Early Middle Pleistocene Horse. Nature 499(7456):74-78.

O'Shea, John M., and John Ludwickson

1992 Archaeology and Ethnohistory of the Omaha Indians: The Big Village Site. University of Nebraska Press, Lincoln.

Oviatt, Charles G.

2015 Chronology of Lake Bonneville, 30,000 to 10,000 yr BP. Quaternary Science Reviews 110:166-171.

Paruelo, Jose, and W. K. Lauenroth

1996 Relative Abundance of Plant Functional Types in Grasslands and Shrublands of North America. Ecological Applications 6:1212-1224.

Passey, Benjamin, Todd Robinson, Linda Ayliffe, Thure Cerling, Matthew Sponheimer, Maria Dearling, Beverly Roeder, and James Ehleringer

2005 Carbon Isotope Fractionation between Diet, Breath $\mathrm{CO}_{2}$ and Bioapatite in Different Animals. Journal of Archaeological Science 32:1459-1470.

Pederzani, Sarah, and Kate Britton

2019 Oxygen Isotopes in Bioarchaeology: Principles and Applications, Challenges and Opportunities. EarthScience Reviews 188:77-107.

Pin, Christian, Danielle Briot, Chantal Bassin, and Franck Poitrasson

1994 Concomitant Separation of Strontium and Samarium-Neodymium for Isotopic Analysis in Silicate Samples, Based on Specific Extraction Chromatography. Analytica Chimica Acta 298:209-217.

Reimer, Paula J., Edouard Bard, Alex Bayliss, J. Warren Beck, Paul G. Blackwell, Christopher Bronk Ramsey, Caitlin E. Buck, Hai Cheng, R. Lawrence Edwards, Michael Friedrich, Pieter M. Grootes, Thomas P. Guilderson, Haflidi Haflidason, Irka Hajdas, Christine Hatté, Timothy J. Heaton, Dirk L. Hoffmann, Alan G. Hogg, Konrad A. Hughen, K. Felix Kaiser, Bernd Kromer, Sturt W. Manning, Mu Niu, Ron W. Reimer, David A. Richards, E. Marian Scott, John R. Southon, Richard A. Staff, Christian S. M. Turney, and Johannes van der Plicht

2013 IntCal13 and Marine13 Radiocarbon Age Calibration Curves 0-50,000 Years cal BP. Radiocarbon 55:1869-1887.

Roberts, Patrick, Nimal Perera, Oshan Wedage, Siran Deraniyagala, Jude Perera, Saman Eregama, Michael D. Petraglia, and Julia A. Lee-Thorp

2017 Fruits of the Forest: Human Stable Isotope Ecology and Rainforest Adaptations in Late Pleistocene and Holocene ( 36 to $3 \mathrm{ka}$ ) Sri Lanka. Journal of Human Evolution 106:102-118.

Roberts, Patrick, Mathew Stewart, Abdulaziz N. Alagaili, Paul Breeze, Ian Candy, Nick Drake, Huw S. Groucutt, Eleanor M. L. Scerri, Julia Lee-Thorp, Julien Louys, Iyad S. Zalmout, Yahya S. A. Al-Mufarreh, Jana Zech, Abdullah M. Alsharekh, Abdulaziz al Omari, Nicole Boivin, and Michael Petraglia

2018 Fossil Herbivore Stable Isotopes Reveal Middle
Pleistocene Hominin Palaeoenvironment in "Green Arabia." Nature Ecology \& Evolution 2:1871-1878.

Rohland, Nadin, Eadaoin Harney, Swapan Mallick, Susanne Nordenfelt, and David Reich

2015 Partial Uracil-DNA-Glycosylase Treatment for Screening of Ancient DNA. Philosophical Transactions of the Royal Society of London, Series B, Biological Sciences 370:20130624.

Schubert, Mikkel, Marjan Mashkour, Charleen Gaunitz, Antoine Fages, Andaine Seguin-Orlando, Shiva Sheikhi, Ahmed H. Alfarhan, Saleh A. Alquraishi, Khaled Al-Rasheid, Richard Chuang, Luca Erminia, Cristina Gamba, Jaco Weinstock, Onar Vedat, and Ludovic Orlando

2017 Zonkey: A Simple, Accurate and Sensitive Pipeline to Genetically Identify Equine F1-Hybrids in Archaeological Assemblages. Journal of Archaeological Science 78:147-157.

Scott, Eric, Thomas W. Stafford, Russell W. Graham, and Larry D. Martin

2010 Morphology and Metrics, Isotopes and Dates: Determining the Validity of Equus laurentius Hay, 1913. Journal of Vertebrate Paleontology 30:18401847.

Smith, Stephen, Raymond Mauldin, Cynthia M. Munoz, Robert Hard, Debajyoti Paul, Grzegorz Skrzypek, Patricio Villanueva, and Leonard Kemp

2014 Exploring the Use of Stable Carbon Isotope Ratios in Short-Lived Leporids for Local Paleoecological Reconstruction. Open Journal of Archaeometry 2(1). DOI:10.4081/arc.2014.5306.

Sponheimer, Matt, Darryl de Ruiter, Julia Lee-Thorp, and Andreas Späth

$2005 \mathrm{Sr} / \mathrm{Ca}$ and Early Hominin Diets Revisited: New Data from Modern and Fossil Tooth Enamel. Journal of Human Evolution 48:147-156.

Sponheimer, Matt, Benjamin H. Passey, Darryl J. de Ruiter, Debbie Guatelli-Steinberg, Thure E. Cerling, and Julia A. Lee-Thorp

2006 Isotopic Evidence for Dietary Variability in the Early Hominin Paranthropus robustus. Science 314:980-982.

Steele, Teresa E.

2015 The Contributions of Animal Bones from Archaeological Sites: The Past and Future of Zooarchaeology. Journal of Archaeological Science 56:168-176.

Stewart, Omer C.

1970 The Question of Bannock Territory. In Languages and Cultures of Western North America: Essays in Honor of Sven S. Liljeblad, pp. 201-231. Idaho State University Press, Pocatello.

Taylor, William

2017 Horse Demography and Use in Bronze Age Mongolia. Quaternary International 436:270-282.

Taylor, William Timothy Treal, Jamsranjav Bayarsaikhan, and Tumurbaatar Tuvshinjargal

2015 Equine Cranial Morphology and the Identification of Riding and Chariotry in Late Bronze Age Mongolia. Antiquity 89:854-871.

Taylor, William Timothy Treal, Jamsranjav Bayarsaikhan, Tumurbaatar Tuvshinjargal, Scott Bender, Monica Tromp, Julia Clark, K. Bryce Lowry, Jean-Luc Houle, Dimitri Staszewski, Jocelyn Whitworth, William Fitzhugh, and Nicole Boivin

2018 Origins of Equine Dentistry. PNAS 115:E6707E6715. DOI:10.1073/pnas.1721189115. 
Taylor, William, and Tumurbaatar Tuvshinjargal

2018 Horseback Riding, Asymmetry, and Changes to the Equine Skull: Evidence for Mounted Riding in Mongolia's Late Bronze Age. In Care or Neglect?: Evidence of Animal Disease in Archaeology, edited by Laszlo Bartosiewicz and Erika Gal, pp. 135-154. Archaeopress, Oxford.

Thornhill, Cassidee A.

2016 Equus Ferus Caballus during the Protohistoric in Wyoming: Looking for the Horse in the Archaeological Record. Master's thesis, Department of Anthropology, University of Wyoming, Laramie, Wyoming.

Tipple, Brett J., Luciano O. Valenzuela, and James R. Ehleringer

2018 Strontium Isotope Ratios of Human Hair Record Intra-City Variations in Tap Water Source. Scientific Reports 8(1):3334.

Waran, Natalie K., Nancy Clarke, and Mark Farnworth 2008 The Effects of Weaning on the Domestic Horse (Equus caballus). Applied Animal Behaviour Science 110:42-57.

Webb, S. David, and C. Andrew Hemmings

2006 Last Horses and First Humans in North America. In Horses and Humans: The Evolution of Human-Equine Relationships, edited by Sandra Olsen, Susan Grant, Alice Choyke, and Lazlo Bartosiewicz, pp. 11-25. British Archaeological Reports, Oxford.

Weber, Jill Ann

2008 Elite Equids: Redefining Equid Burials of the Midto Late 3rd Millennium BC from Umm el-Marra,
Syria. In Archaeozoology of the Near East VIII, edited by Emanuel Vila, Lionel Gourichon, Alice Choyke, and Hijlke Buitenhui, pp. 499-519. Travaux de la Maison de l'Orient et de la Méditerranée 49, Lyon, France.

Wertin, Timothy M., Sasha C. Reed, and Jayne Belnap

$2015 \mathrm{C}_{3}$ and $\mathrm{C}_{4}$ Plant Responses to Increased Temperatures and Altered Monsoonal Precipitation in a Cool Desert on the Colorado Plateau, USA. Oecologia 177:997-1013.

Wolverton, Steve

2013 Data Quality in Zooarchaeological Faunal Identification. Journal of Archaeological Method and Theory 20:381-396.

Zazzo, Antoine, Sébastien Lepetz, Jérôme Magail, and Jamyian-Ombo Gantulga

2019 High-Precision Dating of Ceremonial Activity around a Large Ritual Complex in Late Bronze Age Mongolia. Antiquity 93:80-98.

Zazzo, Antoine, André Mariotti, Christophe Lécuyer, and Emile Heintz

2002 Intra-Tooth Isotope Variations in Late Miocene Bovid Enamel from Afghanistan: Paleobiological, Taphonomic, and Climatic Implications. Palaeogeography, Palaeoclimatology, Palaeoecology 186:145161.

Submitted April 19, 2020; Revised September 7, 2020;

Accepted September 7, 2020 